\title{
Smart Mesoporous Silica Nanoparticles for Protein Delivery
}

\author{
Hai-Jun Liu and Peisheng $\mathrm{Xu}$ * \\ Department of Discovery and Biomedical Sciences, College of Pharmacy, University of South Carolina, \\ 715 Sumter, Columbia, SC 29208, USA; HAIJUN@mailbox.sc.edu \\ * Correspondence: xup@cop.sc.edu; Tel.: +1-803-777-0075
}

Received: 10 March 2019; Accepted: 23 March 2019; Published: 2 April 2019

\begin{abstract}
Mesoporous silica nanoparticles (MSN) have attracted a lot of attention during the past decade which is attributable to their versatile and high loading capacity, easy surface functionalization, excellent biocompatibility, and great physicochemical and thermal stability. In this review, we discuss the factors affecting the loading of protein into MSN and general strategies for targeted delivery and controlled release of proteins with MSN. Additionally, we also give an outlook for the remaining challenges in the clinical translation of protein-loaded MSNs.
\end{abstract}

Keywords: mesoporous silica nanoparticle; protein delivery; controlled release; stimulus responsive MSN

\section{Introduction}

Recombinant human insulin (humulin), the first recombinant protein therapeutic was developed and launched by Herbert Boyer, and Eli Lilly opened the Pandora's box in pharmaceutical proteins 30 years ago [1]. Thus far, there are more than 130 pharmaceutical proteins have been approved by the US Food and Drug Administration (FDA) [2], and large quantities of candidates are being tested in preclinical and clinical development, providing effective treatments and diagnostics for almost every field of diseases and disorders, such as cancer, immunological diseases, infectious disease, and neurogenic disease. [3]. Not only do the primary amino acid sequences of pharmaceutical proteins endow their specific therapeutics but also their sophisticated three-dimensional or spatial structures. Two sides of a coin, this delicate spatial structure of proteins is also the root of a great challenge which hampers the use of protein therapeutics, referring to their susceptibility and frangibility to physical and chemical degradation, as well as physical unfolding, misfolding, and aggregation, resulting in decline or loss of biological activity, immunogenicity and relatively short half-life [4-6]. When protein therapeutics are orally and transdermally administrated, limited bioavailability even ineffectiveness is another enormous challenge owing to poor membrane permeability, large molecular size, generally negative charge, as well as of hydrophilicity property $[7,8]$. In the past decades, extensive efforts have been involved in the design and construction of a versatile therapeutic protein delivery system to overcome the above dilemma and improve their pharmacokinetic and pharmacodynamic properties [5], such as chemical modification $[9,10]$, or encapsulation with polymeric hydrogels, lipid-based protein formulations [11], nanoparticles [12], and microspheres [13,14]. Due to their unique chemical, physical and biological properties, nanoparticles such as liposomes, polymer micelles, polymersomes, inorganic nanoparticles (silica nanoparticles, magnetic nanoparticles, and gold nanoparticles), etc. have gained extensive attention in the field of as a vector for the delivery of protein [15]. Nanoparticles, whose size ranges between 1 and $1000 \mathrm{~nm}$, comprising of natural materials, synthesized materials or their hybrids can entrap or encapsulate, adsorb, or attach therapeutic drugs or biologically agents, thereby the pharmacokinetic behavior of protein therapeutics could be partially substituted or determined by 
the property of nanoparticles, including composition, size, surface potential, and ligand decoration and so on.

Generally speaking, all of these kinds of nanoparticles could achieve relatively improved protein therapeutic benefits in some degree, including: (a) protect protein from premature degradation, (b) prolong protein circulation time, (c) mask their epitope and subsequent immunogenicity, (d) realize their targeted delivery and controlled release, (e) enhance therapeutic efficacy, whereas reducing side effects. However, premature protein leakage, degradation, and limited release deriving from the soft property of liposomes, degradation of polymer matrixes, and chemical modification, respectively, are major challenges that these nanoparticles have to address when they serve as protein drug-delivery vehicles.

Due to its ease of synthesis, facile surface multi-functionalization, preeminent biocompatibility as well as excellent physicochemical and thermal stability, mesoporous silica nanoparticles (MSN) have gained great attention as excellent delivery vehicles [16-20] for drugs, genetic materials, and protein biomacromolecules since the first MCM-41 type MSN was synthesized by Mobil in 1992 [21]. Additionally, MSN can also realize controlled release and targeted delivery of cargoes by optimizing their size, shape and surface modification $[19,22,23]$. Many reviews have exhaustively summarized the synthesis of MSN and applications in drug delivery, whereas fewer involved in protein delivery. In this review, we will give an overview of the application of MSN in therapeutic protein delivery, discuss factors affect the loading of protein to MSN, and also demonstrate general strategies for targeted delivery and controlled release of proteins with MSN. Additionally, we will also look at MSN in co-delivery of protein and other drugs and clinic translations for protein.

\section{Mesoporous Silica Nanoparticles (MSN) as Carriers for Protein Drugs}

Since the first discovery of MCM-41 type MSN in 1992 [21] and the first report of MSN as a drug-delivery vehicle in 2001 [24], it has gone through booming development in its synthesis and application in biomedical field. Mesoporous silica nanoparticles, frequently spherical morphology, are commonly synthesized by condensation of organosilane precursors around organic micelles via a base-catalyzed sol-gel process. After removing or etching the template micelle, ordered arrays of hexagonal or honeycomb-like mesoporous channels would appear in the silicon oxide matrix. Within the MSN family, SBA-15 and MCM-41 are the two types of most commonly used MSNs as a protein delivery system. By altering the synthetic condition, such as $\mathrm{pH}$ [25], the ratio of silica precursor to surfactant [26], pore expanding agent incorporation [27,28], and hybrid of a template or solution [29,30], its size, pore diameter, and morphology can be tuned. Furthermore, the facile functionalization of MSN with organic or inorganic moieties, typically carried out by one-pot synthesis (co-condensation) and/or post-synthesis (grafting), makes it easy to realize designed loading and controlled release of specific cargoes. For example, Lin and co-worker synthesized an MCM-41 MSN with a large pore size $(5.4 \mathrm{~nm})$, and demonstrated that it could not only delivery cytochrome c, a cell membrane impermeable protein into Hela cells, but also could release it intracellularly [31]. Moreover, the released cytochrome c still reserved its catalytic activity. Generally speaking, there are several superiorities by using MSN as a protein delivery system: i) High protein-loading capacity can be achieved with the large pore volumes $\left(>1 \mathrm{~cm}^{3} / \mathrm{g}\right.$ ) of MSNs. ii) The chemically and mechanically stable inorganic oxide framework of MSNs shelters the cargo protein from exposure to harmful species. iii) It has been previously proved that MSNs are capable of escaping endo-lysosomal entrapment due to the $\mathrm{pH}$ buffering properties [31-33]. The following Table 1 gives a summary of the application of MSN in protein delivery. 
Table 1. Functional mesoporous silica nanoparticles for protein delivery.

\begin{tabular}{|c|c|c|c|c|}
\hline The Type of MSN & Modification & Proteins & Cell or Disease Models & References \\
\hline MSN & Propylthiol & Cytochrome C & HeLa cells & [34] \\
\hline MSN & Amino (-NH2), carboxyl $(-\mathrm{COOH})$ & $\begin{array}{l}\text { Glucose oxidase (GOX) and glucose } \\
\text { isomerase (GI) }\end{array}$ & No & [35] \\
\hline FDU-12 & $\begin{array}{l}\text { Aminopropyltriethoxysilane (APTES), } \\
\text { 3-mercaptopropyltrimethoxysilane } \\
\text { (MPTMS), vinyltrimethoxysilane } \\
\text { (VTMS), and phenyltrimethoxysilane } \\
\text { (PTMS) }\end{array}$ & Bovine serum albumin & No & [36] \\
\hline BSA-15 & Aminosilanes & Lysozyme (LYS) and Myoglobin (MYO) & No & [37] \\
\hline BSA-15 & Aminosilanes & Bovine serum albumin (BSA) & No & [38] \\
\hline MSN & Boronic acid & $\begin{array}{l}\text { Insulin and cyclic adenosine } \\
\text { monophosphate (cAMP) }\end{array}$ & Rat pancreatic RIN-5F cells & [39] \\
\hline MSN & $\begin{array}{l}\text { Glycidoxypropyltrimethoxysilane } \\
\text { (GPTMS), chitosan }\end{array}$ & Bone morphogenetic protein-2 (BMP-2) & $\begin{array}{l}\text { Bone mesenchymal stem cells } \\
\text { (bMSCs), Bone regeneration }\end{array}$ & [40] \\
\hline MSN & $\begin{array}{l}\text { 3-aminopropyltrimethoxysilane } \\
\text { (APTMS) }\end{array}$ & $\begin{array}{l}\text { Superoxide dismutase (SOD) and } \\
\text { glutathione peroxidase (GPx) }\end{array}$ & $\begin{array}{l}\text { Inflammation and oxidative } \\
\text { stress }\end{array}$ & [41] \\
\hline MSN & $\begin{array}{l}\text { 3-aminopropyltrimethoxysilane } \\
\text { (APTMS) }\end{array}$ & Superoxide dismutase (SOD) & HeLa cells & [42] \\
\hline BSA-15 & 3-aminopropyltriethoxysilane (APTMS) & Bone morphogenetic protein 2 (BMP-2) & $\begin{array}{l}\text { Bone marrow stromal cells } \\
\text { (BMSCs) }\end{array}$ & [43] \\
\hline MSN & $\begin{array}{l}\text { 2-[methoxy(polyethylenoxy)-propyl] } \\
\text { trimethoxysilane (PEG-silane) }\end{array}$ & Luciferase & Hela cells & [44] \\
\hline $\begin{array}{l}\text { Hollow mesoporous silica } \\
\text { capsules (HMSCs) }\end{array}$ & $\begin{array}{l}\text { Carboxyl, Amino, 5-aminofuorescein } \\
\text { (AFL) }\end{array}$ & BSA, Goat IgG & HeLa cells & [45] \\
\hline MSN & $\begin{array}{l}\text { 2-(methoxy [polyethyleneoxy]propyl) } \\
\text { trimethoxysilane }\end{array}$ & $\begin{array}{l}\text { BSA, macrophage colony-stimulating } \\
\text { factor and receptor }\end{array}$ & Zebrafish embryos/larvae & [46] \\
\hline MSN & $\begin{array}{l}\text { Soluble CD4 ("sCD4"), } \\
\text { amide-immobilized sCD4, 18-peptide } \\
\text { CD4 fragment }\end{array}$ & HIV-1 gp120 Glycoprotein & No & [47] \\
\hline SBA-15 & Unmodified & Porcine pancreas lipase (PPL) & Catalyst & [48] \\
\hline
\end{tabular}


Table 1. Cont

\begin{tabular}{|c|c|c|c|c|}
\hline The Type of MSN & Modification & Proteins & Cell or Disease Models & References \\
\hline MSN & Unmodified & $\beta$-galactosidase & N2a cell & [49] \\
\hline MSN & Gold nanoparticle & $\begin{array}{l}\text { BSA and enhanced green fluorescent } \\
\text { protein (eGFP) }\end{array}$ & $\begin{array}{l}\text { Onion epidermis cells (plant } \\
\text { cell) }\end{array}$ & [50] \\
\hline MSN & PEGylated & BSA & No & [51] \\
\hline SBA-15 & $\begin{array}{l}\text { 3-aminopropyltriethoxysilane (APTES), } \\
\text { 3-mercaptopropyltrimethoxysilane (MPTMS), } \\
\text { phenyltrimethoxysilane (PTMS), vinyltriethoxysilane } \\
\text { (VTES), and 4-(triethoxysilyl)butyronitrile (TSBN) }\end{array}$ & Penicillin G acylase (PGA) & No & [52] \\
\hline MSN & 3-aminopropyltriethoxysilane (APTES) & Carbonic anhydrase (CA) & $\begin{array}{l}\text { Human cervical cancer (HeLa) } \\
\text { cells }\end{array}$ & [53] \\
\hline MSN & $\begin{array}{l}\text { Poly(ethyleneimine)-b-poly( } N \text {-isopropylacrylamide) } \\
\text { (PEI/NIPAM) }\end{array}$ & $\begin{array}{l}\text { Trypsin inhibitor protein (type II-S), } \\
\text { catalase }\end{array}$ & No & [54] \\
\hline
\end{tabular}




\section{The Factors that Affect Protein Loaded into MSN}

\subsection{Pore Size}

Pore size is one of the most important parameters of MSN for loading guest molecules, especially biomacromolecules, such as proteins. The pore opening is regarded as a size-selected adsorption characteristic of drugs. When a protein's size is larger than the pore diameter of a MSN, excepting some protein adsorption on the surface of MSN, the frame work of the MSN is void due to its inaccessibility. Thus, the huge volume and large internal surface area are not sufficiently utilized. Katiyar and Pinto reported the first visualization of a protein-protein separation using SBA-15 materials based on the size difference between the pore and proteins (lysozyme (LYS) and bovine serum albumin (BSA)) [55]. BSA and proteins lysozyme were labeled with Texas Red and LYS Alexa Fluor 488, respectively, and then co-incubated with different MSNs. By using confocal scanning laser microscopy (CLSM), it clearly showed that the smaller protein lysozyme was adsorbed into the pores of SBA-15, whereas the larger BSA was restricted outside the surface of SBA-15, not inside cavity of the pores (Figure 1), giving a visual representation of the influence of a pore on protein loading. Recently, Qiu and co-workers further synthesized three kinds of MSNs with ultra large pores (20, 33 and $40 \mathrm{~nm}$ respectively) and interconnected channel structures by using Brij-56 and Brij-97 as templates and ethyl acetate (EA) and dimethyl o-phthalate (DOP) as additives [56]. These MSNs also showed effective performance in size-selective adsorption of 50-55, 60-65 and 70-100 kDa proteins, respectively, demonstrating great potential in protein load and separation. Therefore, it becomes absolutely necessary to optimize the pore size of MSN depending on the size of the protein. Generally, the pore size is mainly determined by the type and property of surfactant templates and pore expanding agent, and the reaction condition such as temperature also has great influence on pore size.
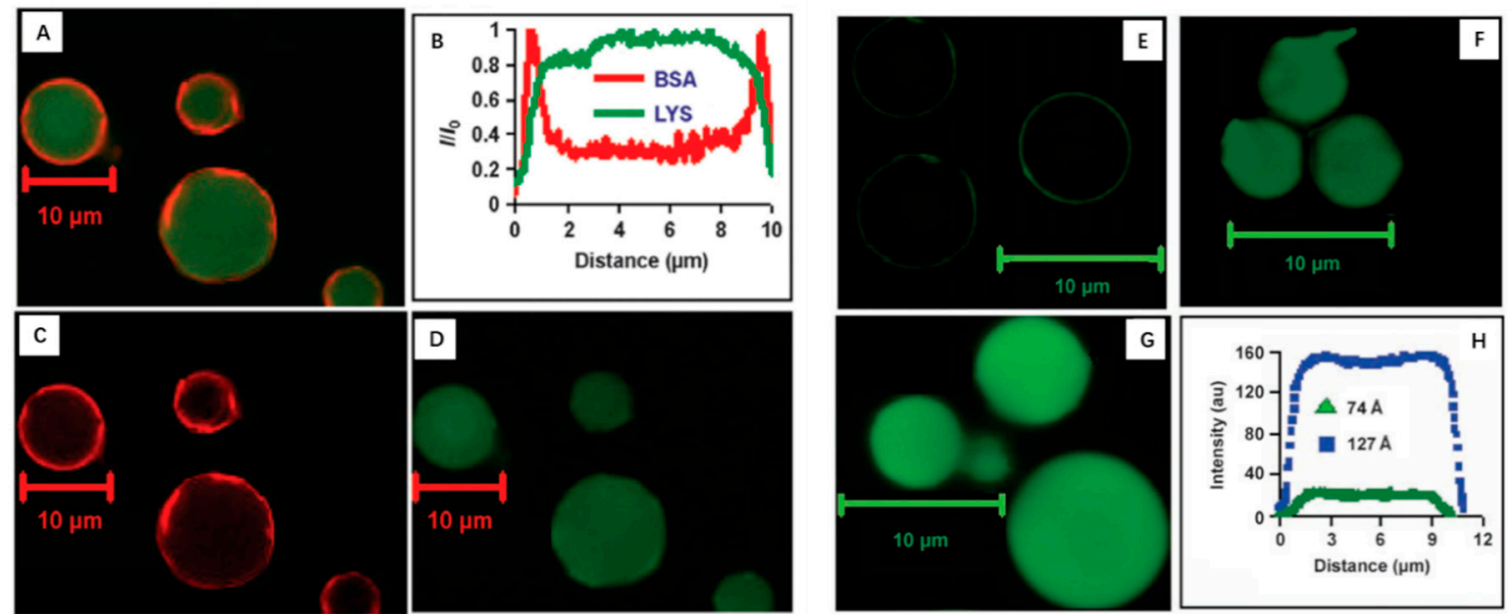

Figure 1. The pore size-selective adsorption and separation of proteins on spherical SBA-15 mesoporous silica nanoparticles (MSN) at pH7.1 (A-D). (A) Merge confocal scanning laser microscopy (CLSM) image of protein adsorbed in SBA-15 (127 ̊) (red, Texas Red labeled bovine serum albumin (BSA); green, Alexa Fluor 488 labeled lysozyme (LYS)). (B) Normalized protein density along with distance. (C) BSA image. (D) LYS image. The LYS adsorption in SBA-15 MSN with different pore sizes (E-H). (E)

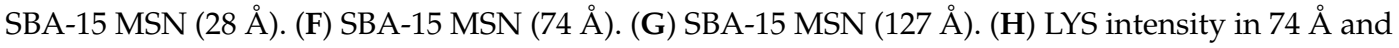
$127 \AA$ SBA-15 [55].

By using an environmentally friendly pore-forming agent tannic acid (TA) as a non-surfactant template, Gao and Zharov demonstrated a one-pot synthesis of a novel large interconnected pore MSN(TA-MSN) [57]. This kind of TA-MSNs possessed a uniform diameter of $200 \mathrm{~nm}$, large pores (6-13 nm) morphology. Moreover, TA-MSN showed a much higher protein loading capacity of $77.1 \mathrm{mg} / \mathrm{g}$ for lysozyme, $396.5 \mathrm{mg} / \mathrm{g}$ for bovine hemoglobin (BHb), $130.0 \mathrm{mg} / \mathrm{g}$ for bovine serum 
albumin, $421 \mathrm{mg} / \mathrm{g}$ for mitochondrial malate dehydrogenase (m-MDH), demonstrated their great potential for biomedical and catalysis applications.

A variety of additives have been employed as pore size expanding agents, such as $\mathrm{N}, \mathrm{N}$-dimethylhexadecylamine (DMHA) [58], trimethylbenzene (TMB) [58,59], aromatic hydrocarbons [60], axiliary alkyl surfactant [61], long-chain alkanes [62,63]. Lin et al. first synthesized and characterized an MCM-41-type mesoporous silica nanoparticle (MSN) material with a large average pore diameter $(5.4 \mathrm{~nm})$ by using mesitylene as a pore expanding agent, and employed it as a transmembrane delivery vehicle for proteins [31]. They demonstrated that the MSN could host a cell-membrane-impermeable protein cytochrome $\mathrm{C}$ and release it into the cytoplasm. By using a block copolymer (Pluronic F127) and an organic solvent (1,3,5-trimethylbenzene, TMB) as templates and alkanes/ethanol as pore expanding agents [64], Kao and Mou synthesized a series of pore expanded MSN with the help of inorganic salts $(\mathrm{KCl})$. Among the finite alkanes (hexane, octane, decane, dodecane, and hexadecane), they found decane was the most effective expanding agent, yielding MSN materials with enlarged pores $(5.6 \mathrm{~nm})$ and well-ordered mesostructure. They also studied the effects of the amount and ratio of ethanol and ammonia solution $\left(\mathrm{NH}_{4} \mathrm{OH}\right)$ on pore size and pore structure. Fan and co-worker demonstrated a new way to construct a large pore size of highly ordered MSN (around $27 \mathrm{~nm}$ ) with entrance dimensions that varied from 4 to $16.7 \mathrm{~nm}$ at a low synthesis temperature [65]. Temperature may be critical to the structures and morphology of this type of MSN due to the flexible shape of the template micelle in low temperature.

Generally speaking, when MSN size remains fixed, the larger pore size, the bigger volume for protein loading. Kao and Mou synthesized a series of pore-expanded MSNs by using different ratios of decane/ethanol as pore-expanding agents, and then compared the amount of immobilized lysozyme into the pore-expanded MSN and conventional MSN with pore sizes of 5.6 and $2.5 \mathrm{~nm}$, respectively. They found the adsorption capacity of pore-expanded MSN is up to $420 \mathrm{mg}$ lysozyme per gram MSN, which is obviously larger than that of the conventional MSN materials (340 mg lysozyme per gram of MSN) [64], demonstrating the great potential in intra-pore confinement of enzyme and protein.

\subsection{Surface Functionalization}

Silanol groups $(\mathrm{Si}-\mathrm{OH})$, presenting on the surface of MSN in the concentration of at least 2-4 groups/nm [66], give the base for decorating MSN with various silyl reagents. MSN can be modified or grafted with different functional groups on its mesopore channel and/or external surface, resulting in various surface groups, zeta potentials, and hydrophilic and hydrophobic properties. The ability to selectively functionalize the external and internal surface of MSNs opens infinite possibilities in the field of drug delivery, especially for protein delivery. The main interactions between the surface groups of MSN and gusts are chemical interaction and physical interaction (such hydrogen bonding and electrostatic interactions). Many studies have demonstrated that the proteins loading capacity of functionalized MSN would be greatly enhanced compared with its un-functionalized or native counterparts [33-35]. Owing to negative potential of most proteins, positively charged amino silyl reagents or polymers are the most widely functional groups used for protein adsorption and binding. Table 1 is a summary of complexes of different functional MSN with proteins. Actually, aminosilane functionalized silica nanoparticles have been widely applied to the adsorption and release profile study of proteins, such as lysozyme, bovine serum albumin and myoglobin [37,67]. Ackerman and co-workers reported $\mathrm{NH}_{2}$-functionalized mesoporous silica (FMS) with large pore size can realize a highly efficient negatively charged protein confinement or immobilization in comparison with unfunctionalized mesoporous silica and normal porous silica [35]. In the meantime, the loaded negatively charged glucose oxidase (GOX) and glucose isomerase (GI) displayed a comparable immobilization efficiency $\left(\mathrm{I}_{e}\right)$ than the free enzyme in a range from $30 \%$ to $160 \%, 100 \%$ to $120 \%$, respectively. Kawi et al. demonstrated that amino functionalized SBA-15 MSNs had more BSA absorption capacity than bare ones due to the strong electrostatic interaction between positively amines and negatively charged BSA [68]. 
By decorating with citraconic amide functionality on the pore surfaces of mesoporous silica nanoparticle, Lee and co-workers constructed a smart protein delivery system, which could undergo responsive charge conversion in endosomal conditions and release cytochrome c [69]. Lu et al. synthesized a series of functionalized FDU-12 mesoporous silica nanoparticles via co-condensation of etraethoxysilane with a suite of organosilanes, such as 3-aminopropyltriethoxysilane (APTES), 3-mercaptopropyltrimethoxysilane (MPTMS), vinyltrimethoxysilane (VTMS), and phenyltrimethoxysilane (PTMS) by using Pluronic F127 and trimethylbenzene (TMB) as template and pore expanding agent, respectively [36]. They used cellulase, a cellulose-hydrolyzing enzyme as a model protein, and studied the effect of organic functionality on enzyme immobilization efficiency, activity, and stability varied significantly. Due to the size exclusion effects at pore entries from functionality, PTMS and MPTMS functionalized MSN had a very low loading capacity of cellulase. Although APTES functionalized MSN had the highest adsorption efficiency of cellulase by mean of strong electrostatic interactions between amino-functionalized surfaces and enzymes, the enzymatic activity of cellulase would be compromised due to the formation of amide bonds between cellulase and APTES, which led to a loss of active site and change in enzyme spatial structure. Attributed to hydrophobic interaction between cellulase and the vinyl moiety, VTMS-functionalized MSN not only exhibited a strong affinity for the cellulase but also maintained a stable enzyme conformation activity, and appeared to be the most promising approach in these motifs.

\subsection{Targeting Protein Delivery}

Since target tissue/cells have abnormal expression and/or overexpression of particular receptors, the surface of a MSN can be functionalized with corresponding moieties or ligands, such as peptides [70-72], proteins [73,74], antibodies [75-77] and aptamer [78,79], which have high selectivity and affinity to those receptors. Thus, the functionalized MSN can achieve active targeted delivery of the protein cargoes to its destination. By conjugating TAT cell penetrating peptide and transferrin to the surface of MSNs, Chen and co-workers developed a multifunctional mesoporous silica nanoparticles delivery system for selenoamino acid, a new kind of antitumor drug, achieving synergistic chemo-/radiotherapy through death receptor-mediated extrinsic apoptotic pathway [80]. In this system, TAT peptide and transferrin were employed as targeting ligands to enhance MSN internalization by a cancer cell in vitro and in vivo through receptor-mediated endocytosis.

It was found that CD44 is highly expressed in some multidrug resistance cancers, such as multidrug resistance (MDR) breast cancer, involving in P-glycoprotein (P-gp) mediated drug efflux and overexpression of the anti-apoptotic protein Bcl-xL [81,82]. Lu and co-workers developed a CD44 monoclonal antibody-functionalized, doxorubicin (DOX)-loaded mesoporous silica nanoparticle as a targeted drug delivery system for enhancing chemosensitivity and overcoming multidrug resistance in vitro and in vivo [83]. CD44 McAb was functionalized on the surface of the MSN through the formation of amide bonds. In the system, CD44 McAb not only served as an active targeting ligand through antigen-antibody reaction but also sensitized the chemotherapeutic efficacy of DOX by reversing the MDR effect (Figure 2). 


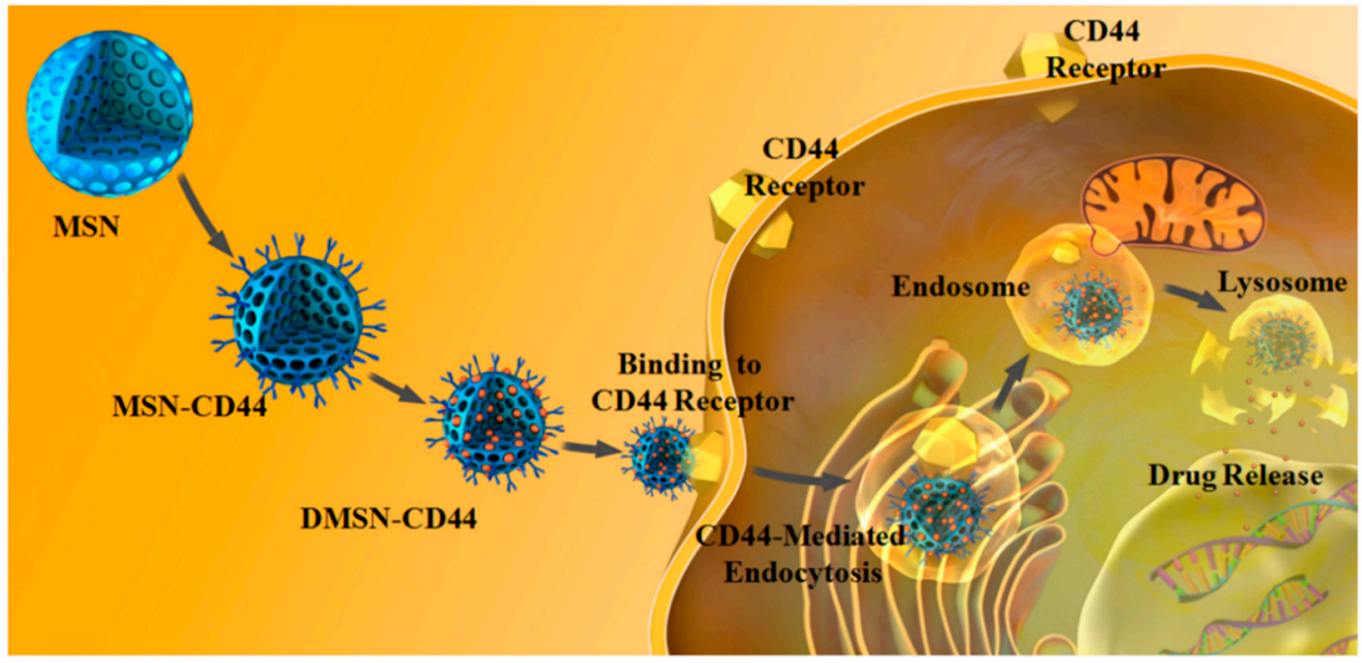

Figure 2. Schematic illustration of an MSN-based protein (CD44 McAb) and chemotherapy drug targeted co-delivery system and overcome multidrug resistance in MCF-7/MDR1 breast cancer cells [83].

\subsection{MSN-Based Combination Therapy of Protein and Other Therapy Models}

Many diseases, especially cancer, central nervous diseases, and immunological disease are usually caused by multiple factors. The heterogeneity, complexity of the signaling network and adaptive resistance make them a formidable challenge to defeat. Generally, monotherapy strategy for killing given cells or regulation of a specific target pathway would only yield compromised therapeutic efficacy. Consequently, this can induce the emergence of drug resistance after multiple dosing due to the activation of a compensatory mechanism. Thus, combination therapy with two or more therapeutic agents with complementary or synergistic effect is commonly employed, including the combo of therapeutic proteins and other molecules. In the area of drug delivery, especially nanocarriers, it has been a hot sub-field to develop efficient vehicles that could simultaneously deliver two or more kinds of therapeutic molecules or realize two or more therapeutic models in a coordinated manner. Due to the great difference in physicochemical properties between proteins and other therapeutic molecules, such as size, surface charge, friability, and sensibility, it is a big challenge to accomplish their co-delivery for conventional drug delivery systems. With tunable pore size, various surface functionalization, and enormous interior and exterior particle surface, MSNs could be a promising co-delivery platform for proteins and other therapeutic guest molecules to realize controlled release in a rational manner.

By using hydrophobic indomethacin (IMC) and hydrophilic human peptide YY3-36 (PYY3-36) as model drugs, Santos et al. investigated the potential of MSN for co-delivery drugs with various physicochemical properties, the effect of co-delivery manner on their release profiles and drug-permeation profiles [84]. They revealed that a co-loading procedure could increase the overall loading efficiency of MSN, accelerate drug release rate and promote their permeation behavior. The loading model, single or dual drugs loaded into MSN, had no influence on their permeation profiles. Furthermore, conformational analysis indicated that PYY3-36 could retain its space structures after intestinal cell monolayer permeation and display biological activity after being released from the MSN, indicating promising candidates for the co-loading of hydrophilic and hydrophobic therapeutics.

Shi and co-workers develop chitosan (CS) and mesoporous silica nanoparticle composite hydrogels for the co-delivery of biomacromolecules, bovine serum albumin (BSA), and small chemical drugs gentamicin (GS) [85]. The embedding of MSN in the CS gel would accelerate the gelation rate and enhance its mechanical strength. In addition, MSNs could act as a drugs container and realize cargoes with sustained release. The release of GS and BSA from CS/MSN hydrogels presented a sustained manner simultaneously, compared to single sustained release of BSA from CS hydrogels. 
In vitro chondrocyte culture demonstrated the CS/MSN composite hydrogels has a great potential in the noninvasive therapy of cartilage regeneration.

Owning to the relative bulk volume and size, proteins drugs can also act as MSN pore blocker to achieve controlled release of drugs. Zhao and co-works synthesized a glucose-responsive MSN based co-delivery system for insulin and cAMP, realizing controlled (Figure 3) sequence release [39]. In the system, insulin modified with gluconic acid and immobilized on the MSN exterior surface through reversible covalent bonding between phenylboronic acid and acyclic diols was not only a model protein drug but also acted as a pore cap to encapsulate cAMP molecules inside the mesopores of MSN. Adjacent diols of saccharides, such as glucose and fructose can competitively form stable cyclic esters with phenylboronic acid than with acyclic diols, thus trigger insulin release from MSN and subsequently the encapsulated cAMP. The cAMP delivery into the cytosol of pancreas beta cells would stimulate insulin secretion. This showed that the triggered insulin release was completed within $30 \mathrm{~min}$, and this interval frame was sufficient for normal insulin secretion. Thus, the decrease of insulin release with repeated cycles of conventional glucose-responsive insulin delivery systems would be overcome by this kind of self-regulated insulin-release [86].
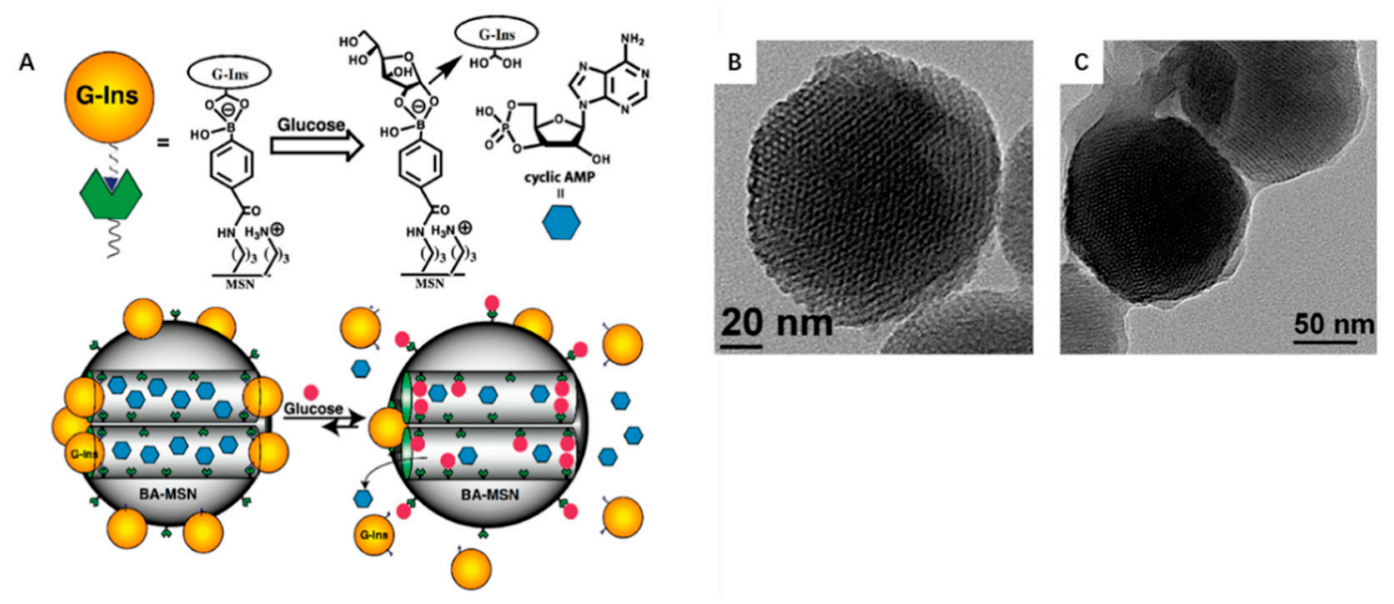

Figure 3. (A) Schematic illustration of a double drugs co-delivery system for controlled release of bioactive G-Ins and cAMP. cAMP is confined into the MSN pore; G-Ins is modified on the surface as a pore cap. (B) Transmission electron micrograph (TEM) of boronic acid-functionalized MSN. (C)TEM of FITC-G-Ins-capped MSN [39].

\section{MSN-Based Stimuli-Responsive Delivery System for Proteins}

The stimuli-responsive drug-delivery system (SRDDS) can prevent premature release before reaching the disease foci, and release the encapsulated drugs into targeted locations in response to external stimuli or internal local microenvironment difference, which will increase drug efficacy for targeted cells while decreasing the toxicity to normal cells [87,88]. Due to their unique structure and property, MSNs have attracted a lot attention particularly in SRDDS. Two main methods can achieve responsive drug release from MSN. The first method is to conjugate drugs to the surface of the MSN through cleavable covalent bonds, which can be broken in a specific condition. The other method is to cover the surface of the MSN with a strippable coating or cap the pores of the MSN with blockers as gatekeepers, which would open the pore entrance upon the surrounding environment change, such as $\mathrm{pH}$, redox, enzyme, and temperature, etc.

\section{1. pH-Responsive Delivery System}

$\mathrm{pH}$ is the most widely used biological parameter to trigger drug release among various kind of stimuli. Intercellular acidic gradient or distinct difference in $\mathrm{pH}$ between the physiological environment 
and targeting tissue constitute the rationale for $\mathrm{pH}$-responsive drug delivery systems. During the last decade, many $\mathrm{pH}$ responsive MSN-based protein delivery systems have been developed.

Due to its acid lability, imine bond formed between primary amine and aldehyde is widely used to construct $\mathrm{pH}$ responsive delivery system [89,90]. For example, Han et al. synthesized an aldehyde-functionalized MSN (MSN-aldehyde), which could conveniently and efficiently conjugate with model proteins via imine bonds [91]. To track the protein release in the acidic lysosome, the MSN was labeled with lysosome activatable rhodamine-lactams. They demonstrated that the constructed nanocomposites were selectively internalized into lysosomes of model cells, HepG2, HeLa, and L929 cells. The loaded proteins could be efficiently released from MSN upon the trigger of acidic lysosome solution, followed by escaping into the cytoplasm and exhibiting their corresponding function. Zhu et al. also developed aldehyde-functionalized dendritic mesoporous silica nanoparticles (DMSNs-CHO) with an average particle size of $174 \mathrm{~nm}$ and an internal pore size of $7.7 \mathrm{~nm}$ as a potential $\mathrm{pH}$-responsive protein drug delivery system [92]. They loaded BSA as a model protein into the pores of DMSNs-CHO and found its release was dependent on environment $\mathrm{pH}$. The DMSNs-CHO nanoparticles could be efficiently taken up by cells and had no cytotoxicity. All those indicate that MSN-aldehydes would be a promising and versatile vector for the delivery of various proteins into cells.

In another example, Lee and coworkers designed and constructed a smart mesoporous silica nanoparticle, whose pore surface was functionalized with $\mathrm{pH}$-hydrolyzable citraconic amides (MSN-Cit), which could undergo charge conversion in acidic lysosome environment [69]. At physiological $\mathrm{pH}$ ( $\mathrm{pH}$ 7.4), MSN-Cit exhibited negative surface charge due to the terminal carboxyl groups of the citraconic amide. Therefore positively charged cytochrome c (Cyt c) could be loaded into the MSN pore through electrostatic interaction. After MSN-Cit was internalized into acidic lysosome ( $\mathrm{pH} 4-5$ ), surface citraconic amide went through hydrolysis, leading to dramatic charge conversion of MSN from negative to positive $(16 \mathrm{mV})$. The charge repulsion between MSN and Cyt $\mathrm{c}$ would result in Cyt c release. In vitro release profiles demonstrated only 10\% of Cyt c release from MSN-Cit was observed at pH 7.4 in $10 \mathrm{~h}$, whereas more than $30 \%$ of Cyt c was release at pH 5.0 for the same period. Confocal laser scanning microscopy (CLSM) studies proved that MSN-Cit effectively released Cyt c in endosomal compartments. Moreover, this charge reversion strategy also endowed MSN-Cit wonderful biocompatibility and the ability for endosomal escaping. Due to the anionic surface nature of red blood cells (RBC), the negative charge at physiological pH 7.4 made the lysis of (RBCs) by MSN-Cit negligible, even at the concentration of $10 \mathrm{mg} / \mathrm{mL}$. In contrast, the charge reversion to positive in acidic endosomes facilitated MSN-Cit absorb on the surface of lysosome membrane and cause the rupture of lysosomes, resulting in the release of Cyt c delivery into the cytoplasm.

\subsection{Extracellular Glutathione (GSH)-Responsive Delivery System}

It is well known that in normal cells, extracellular glutathione (GSH) concentration is approximately $2-10 \mu \mathrm{M}$ and intracellular concentration is around 2-10 $\mathrm{mM}$ [93]. Moreover, it was found that the GSH concentration in cancer cells is several times higher than that in normal cells [94]. This huge difference in GSH concentration between extracellular and intercellular condition makes redox-responsive vehicles a promising carrier to disassemble and release drugs in the cytosol. Utilizing this difference, Griebenow fabricated a redox responsive carbonic anhydrase (CA) controlled release system by immobilizing it onto the internal surface of mesoporous silica nanoparticles via disulfide bond [53]. The internal surface MSN was pre-functionalized with free thiol group by (mercaptopropyl)-trimethoxysilane (MPTMS), and then the model enzyme CA was covalent conjugated to MSN by using sulfosuccinimidyl 6-[3'(2-pyridyldithio)-propionamido]-hexanoate (Sulfo-LC-SPDP) as a linker at the ratio of 1:1. In vitro protein release profiles demonstrated that the system could response to GSH and release CA from MSN. More importantly, the released CA remained at least $80 \%$ of its enzyme activity. 
Yu et al. first reported a cell-type specific degradable dendritic mesoporous organosilica nanoparticles (DDMONs), which preferentially release protein in cancer cells as opposed to normal cells (Figure 4) [95]. The disulfide bond is homogeneously hybrid into the framework of DDMONs with controllable pore size. The authors studied the pore structure-dependent GSH-responsive degradation behavior in normal cells and tumor cells. They found that only the larger pore DDMONs in tumor cells displayed a much faster degradation rate, indicating efficient protein delivery toward cancer cells, through which selectively kill cancer cells but not normal cells. As a proof of concept, they used ribonuclease A (RNase A) as a model therapeutic protein to demonstrate the benefit of designed DDMONs. In vitro release profiles showed that RNase A displayed obvious GSH-dependent release behavior. It was found that less than $30 \%$ of proteins released from DDMONs after $48 \mathrm{~h}$ incubation in $10 \mu \mathrm{M}$ GSH. By contrast, when GSH concentration increased to $1 \mathrm{mM}$, the release rate of proteins reached $\sim 57 \%$ at $48 \mathrm{~h}$ owing to the partial degradation of DDMONs. Surprisingly, when the GSH concentration further increased to $10 \mathrm{mM}$, a rapid release of protein was observed, reaching $\sim 97 \%$ at $48 \mathrm{~h}$ due to the severe rupture of the pore structure. The author further studied the cell inhibition of RNase A loaded DDMONs in cancer cells and normal cells. It found that degradable DDMONs-PEI/RNase A showed higher cytotoxicity than non-degradable DMONs-PEI/RNase A at all concentrations toward B16F10 cancer cells, which is mainly attributed to intracellular high GSH concentration-triggered nanocarriers degradation. In contrast, in normal HEK293t cells, the cytotoxicity of DMONs-PEI/RNase A is significantly lower than that of DDMONs-PEI/RNase A, due to their relatively lower GSH level. All the results demonstrated the disulfide bond hybrid, redox-responsive degradable MSN could be a superior candidate for protein delivery.
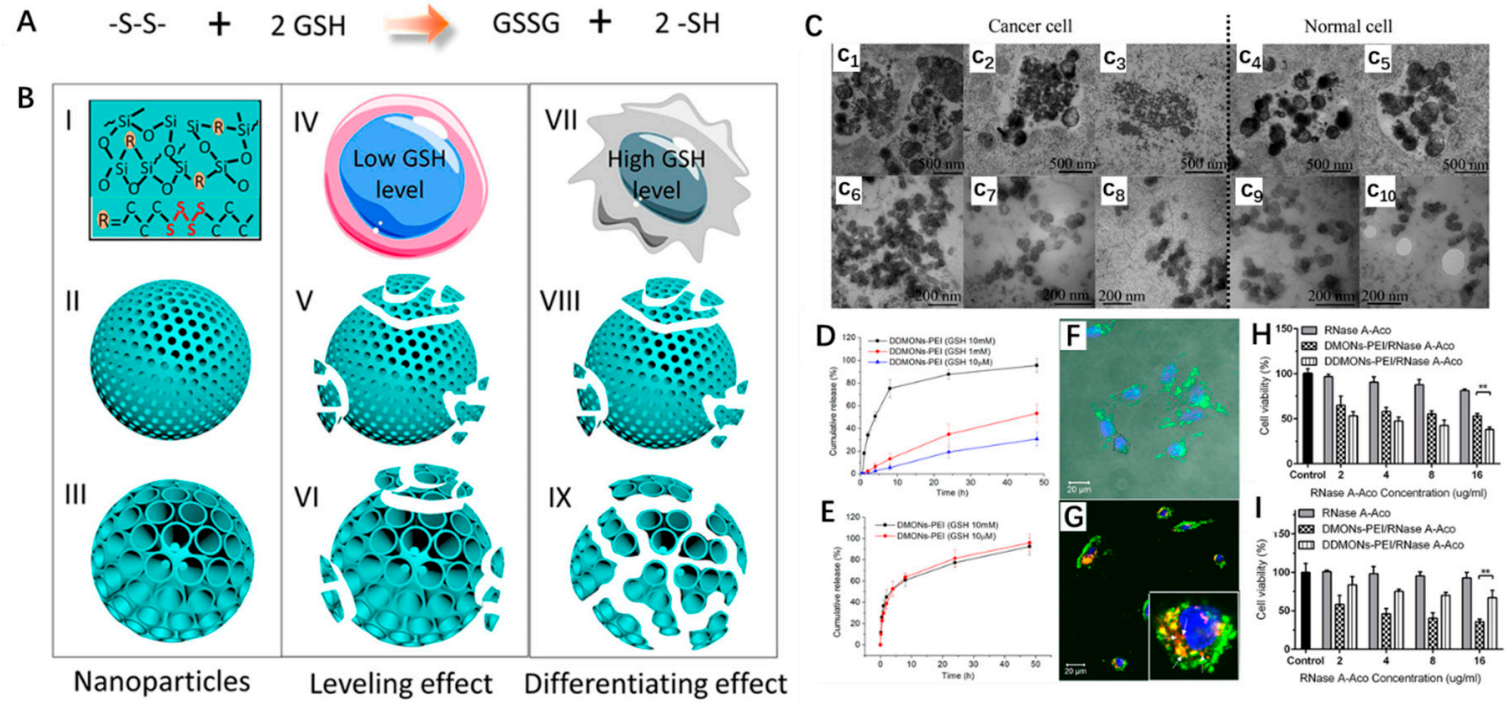

Figure 4. (A) The reaction of the disulfide bond is cut off by extracellular glutathione (GSH). (B) Schematic illustration of pore structure dependent degradability organic-inorganic hybrid mesoporous silica nanoparticles in normal and cancer cells. (I) organic-inorganic hybrid composition of degradable dendritic mesoporous organosilica nanoparticles (DDMONs), (II, V, VIII) small pore MONs, (III, VI, IX) large pore DDMONs, (IV) normal cell, (VII) cancer cell. (C) Intracellular degradation of DDMONs and MONs. DDMONs incubated with B16F10 for $4 \mathrm{~h}(\mathrm{c} 1), 24 \mathrm{~h}(\mathrm{c} 2), 48 \mathrm{~h}$ (c3); DDMONs incubated with HEK293t for $24 \mathrm{~h}(\mathrm{c} 2), 48 \mathrm{~h}(\mathrm{c} 3)$; MONs incubated with B16F10 for $4 \mathrm{~h}(\mathrm{c} 1), 24 \mathrm{~h}(\mathrm{c} 2)$, $48 \mathrm{~h}(\mathrm{c} 3)$; MONs incubated with HEK293t for $24 \mathrm{~h}(\mathrm{c} 2)$. In vitro release of RNase A-Aco from DDMONs-poly(ethyleneimine)-b-poly (PEI) (D) and DMONs-PEI (E) in different release solutions. (F) The uptake of DDMONs-PEI/RNase A-Aco-FITC complex in in B16F10 cells after $10 \mathrm{~h}$ incubation. (G) Confocal images of RNase A-Aco-FITC release from DDMONs-PEI in B16F0 cells for $24 \mathrm{~h}$. Cell viability of B16F10 cancer cell (H) and Hek293t normal cell (I) after incubation with DDMONs-PEI/RNase A-Aco for $48 \mathrm{~h}(* *<<0.01)$ [95]. 


\subsection{Enzyme-Responsive Delivery System}

Enzymes play a very important role in physiological and pathological processes. The unusual expression or upregulated expression of an enzyme in the target site makes it elegant endogenous stimuli due to its high sensitivity and selectivity [96]. Matrix metalloproteinases-2 (MMP-2) are one of the overexpressed proteins in some tumors, which are closely related to tumor invasion and metastasis [97,98]. Cai et al. employed this trait to construct a MMP-2 responsive BSA and DOX co-delivery system [99]. Phenylboronic acid (PBA) is a highly affinitive ligand for sialic acid (SA), a well-known overexpressed protein indicator for tumor metastasis on HepG2 cells [100]. They decorated PBA to human serum albumin (PBA-HSA) and then used an intermediate linker composed of MMP-2 substrate peptide (PVGLIG) and polyarginine (RRRRRRRRR) to conjugate it onto the surface of MSN, resulting in SNs-HSA-PBA@DOX [99]. Before the linker was cut off by MMP-2, the model protein HSA could not only act as a pore seal to prevent DOX from premature release but also made it convenient to decorate PBA ligand on the surface of the MSN for active targeting. After the breakage of the linker, the opened pore entrance would promote the release of the loaded drugs. Through the integration of active targeting and enzymes' control drug release strategies, MSNs-HSA-PBA@DOX achieved enhanced antitumor efficacy both in vitro and in vivo (Figure 5).
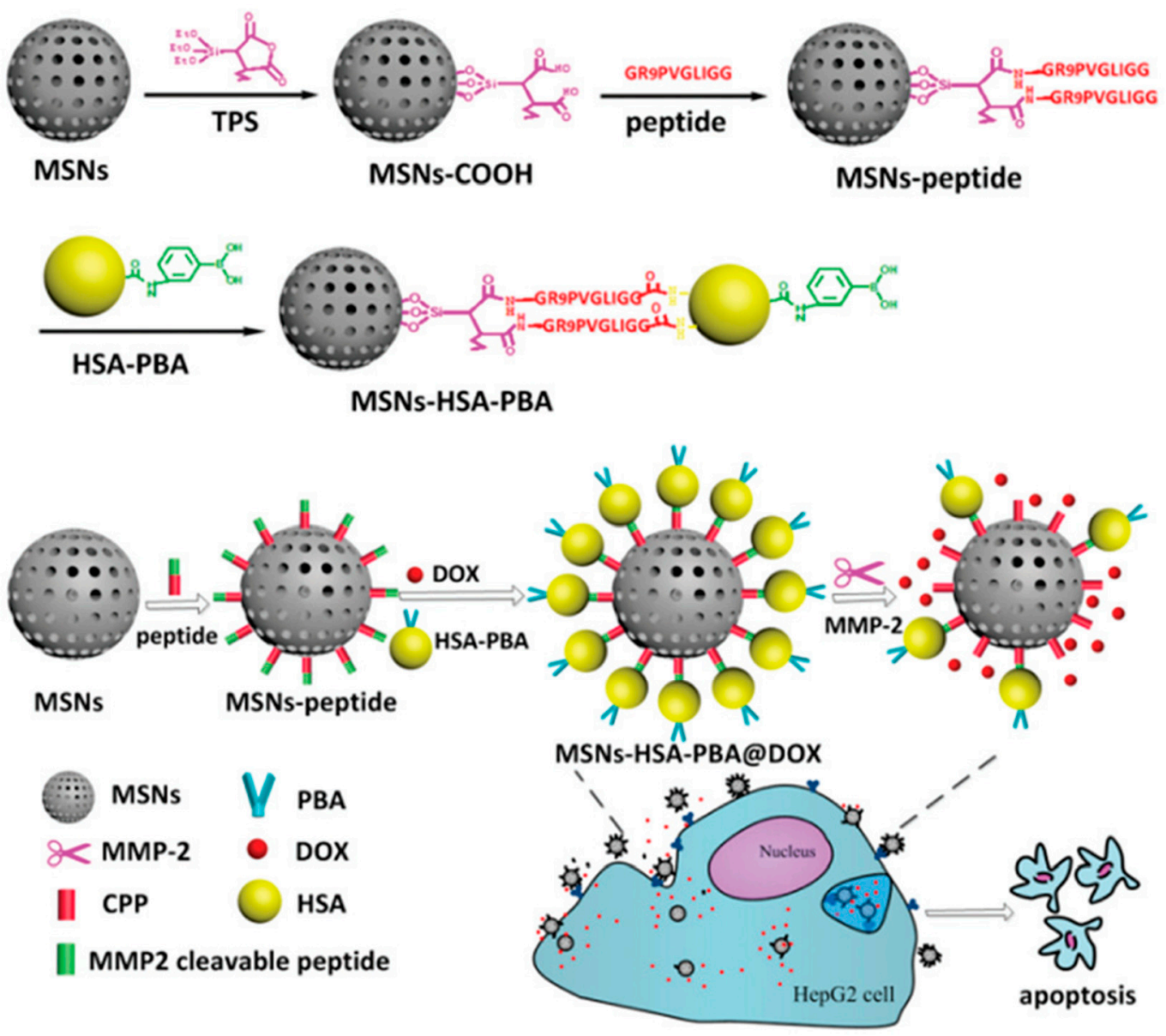

Figure 5. Schematic illustration of the construction of MMP-2 enzyme-responsive mesoporous silica Nanoparticles for the co-delivery of human serum albumin and DOX and its biological effect [99].

\subsection{Heat and Magnetic Responsive Delivery System}

Heat is a very effective stimulus which has frequently been used as a trigger for protein release from MSN-based delivery system. To achieve that, such a complex of the MSN system usually includes MSNs, a thermal conversion agent, a drug, and a temperature-sensitive polymer which can swell above 
certain temperatures (lower critical solution temperature, LCST) and shrink below certain temperatures to facilitate drug release. Stroeve et al. used thermosensitive poly(n-isopropylacrylamide) (PNIPAM) as a gatekeeper to realize controlled bovine hemoglobin $(\mathrm{BHb})$ release [101]. Other than traditional PEGylation on the exterior surface of the MSN to minimize non-specific binding and interactions with the biological environment, they grafted PEG on the interior porous framework to minimize protein adsorption and reduced protein denaturation. Thus, when temperature is raised to higher than the LCST, the PNIPAM gate will open and induce rapidly and sufficiently $\mathrm{BHb}$ releasefrom MSN. Vallet-Regí and co-workers showed a novel MSN-based nanocarrier, which could respond to an alternating magnetic field to remotely control the release of loaded small molecules and protein [54]. Iron oxide nanocrystals served as magnetothermal transfer agents were encapsulated inside the MSN matrix. A thermoresponsive copolymer of poly(ethyleneimine)-b-poly( $N$-isopropylacrylamide) (PEI/NIPAM) was decorated onto the surface of MSN and acted as a temperature-responsive gatekeeper for trapping small molecules in the pore matrix as well as a retainer for proteins buried in the polymer shell by electrostatic and hydrogen bonds interactions. When the nanodevices were placed in an oscillating or alternating magnetic field, the iron oxide nanocrystals would transduce magnetic energy to heat due to the hysteresis loss and/or Néel relaxation to promote polarity inversion and tridimensional polymeric network changes if the heat reaches LCST, subsequently provoking the pore opening and a significant molecules and protein release. Moreover, the magnetic nanocrystals would endow the nanodevices' magnetically targeted ability to the desired place using a permanent magnet. In addition, it can also be employed as contrast agents for magnetic resonance imagining. Similarly, Khashab and co-workers also developed a silica-iron oxide hybrid nanovectors with large mesopores (20-60 nm) for protein (mTFP-Ferritin) loading and delivery to cancer cell [102]. The iron oxide nanophases were homogeneous incorporated into the silica matrix, which made the nanocomplex not only have the ability of magnetically-actuated release of protein but also enhanced the biodegradability of nanovector due to the removal of iron centers from the silica-iron NPs in physiological conditions, exhibiting great promise in biomedical applications.

\subsection{Light-Responsive Delivery System}

Light is an attractive stimulus as a trigger for controlled drug release due to its non-invasive nature, desirable controllability, high spatial resolution and temporal precision with a pulsatile switch on/off model $[103,104]$. Cargo release profiles from a light-responsive delivery system can be controlled by various light parameters, including wavelength, output power, exposure time, beam diameter, and so on. Liu et al. constructed a light-controlled release, MSN-based protein and model drug co-delivery system [105]. A photo-labile copolymer P(OEGMA-co-TENBMA) that could form a protein-polyelectrolyte complex (PPC) with bovine serum albumin (BSA) was anchored on the surface of MSN as a capping agent for the nanopores of the MSNs. The PPC is stable at physiology environment, but P(OEGMA-co-TENBMA) trend to hydrolyze to ionic P(OEGMA-co-MAA) upon ultraviolet (UV)-irradiation on photo-labile 2-nitrobenzyl ester moieties. This charge conversion would lead to the disruption of PPC and subsequent co-release of BSA and small molecule rhodamine B.

\section{Biocompatibility}

For in vivo biomedical applications, it is crucial that nanoparticles can not only achieve their designed mission but also do not produce non-specific and deleterious changes to the body, indicating good biocompatibility. Although silica has been used as an excipient in the pharmaceutical industry for decades, and generally considered as of low toxicity, its in vivo toxic effects have been reported. Thus its toxicity to the body (including acute toxicity and chronic toxicity) should be carefully assessed when it was applied in the body. The exact mechanism for MSN toxicity is still uncertain, and some theories were proposed and evaluated, including the induction of membrane damage [106], generation of reactive oxygen species [107], disruption of lysosome damage, and interruption of cellular respiration [108]. It has been proven that particle size, shape, structure, and surface function 
would have a significant influence on MSN biocompatibility. Although a definite conclusion cannot be drawn between MSN physicochemical properties and biocompatibility owing to the complexity of nanotoxicity, the relationship is still controversial, but a relative clarity will pave the way for their application and clinical translation.

Particle size is one of the most important parameters of MSN, which can have a great influence on MSN biocompatibility. Mou et al. investigated the influence of MSN size on its intracellular internalization by Hela cells [109]. They found that internalized amount of MSN was obvious size-dependent. MSNs with a size of $50 \mathrm{~nm}$ showed the highest cellular uptake by HeLa cells, which was around 2.5 times greater than the uptake of $30 \mathrm{~nm}$ MSNs; while cellular uptake of $110 \mathrm{~nm}$, $280 \mathrm{~nm}$, and $170 \mathrm{~nm}$ MSNs was much lower. The internalized amount of MSNs into Hela cells was in the order $50 \mathrm{~nm}>30 \mathrm{~nm}>110 \mathrm{~nm}>280 \mathrm{~nm}>170 \mathrm{~nm}$, and MSN in $50 \mathrm{~nm}$ size may be the most effective in drug delivery in the aspect of in vitro cellular uptake. Other research conducted by Li et al. demonstrated that cytotoxicity was highly correlated with the size of MSN [110]. They found all investigated MSNs showed low cytotoxicity at or under the concentration of $25 \mu \mathrm{g} / \mathrm{mL}$; but when MSN concentration was above $25 \mu \mathrm{g} / \mathrm{mL}$, MSN with the size of $190 \mathrm{~nm}$ and $420 \mathrm{~nm}$ showed significant cytotoxicity, while microscale MSN $(1220 \mathrm{~nm})$ almost always showed slight cytotoxicity over a broad MSN concentration, ranging from 10 to $480 \mu \mathrm{g} / \mathrm{mL}$. Lin and Haynes also found that porous MSN would cause a concentration- and size-dependent hemolytic cytotoxicity [111]. The smaller particles exhibited higher toxicity than larger particles (in the range from $25 \mathrm{~nm}$ to $263 \mathrm{~nm}$ ) in the concentration range from 3.125 to $1600 \mu \mathrm{g} / \mathrm{mL}$ (Figure 6).

Structural properties of MSN could also affect its biocompatibility, and this effect is especially prominent when it compares to amorphous silica in its hemolytic property. RBCs would be lysed when amorphous silica is at a high concentration. The mechanism accounts for this hemolysis cytotoxicity is mainly based on the interaction between the numerous surface silanol groups of silica materials and the tetra-alkyl ammonium groups on the membrane of RBCs. Although compared with amorphous silica material, highly ordered MSN had more silanols due to a large surface area, but most silanol groups were on the internal surface, which could be attributed to the less negative $\zeta$-potential of the highly ordered MSN $(-35 \mathrm{mV})$ than the one of amorphous silica $(-49 \mathrm{mV})$. The relatively low concentration of external silanols made MSN no-hemolytic on RBCs under determined concentration. Furthermore, the discontinuous external surface silanols due to mesoporosity would lower the hemolytic activity of MSN [112]. Similarly, the shape of MSNs also has some effect on their biocompatibility. Yu et al. constructed several kinds of MSNs with different shapes and studied shape effect on cytotoxicity [113]. Although they found that aspect ratio, ratio of length over width, of MSN had no significant impact on its acute cytotoxicity, cellular uptake, proliferation inhibition, and plasma membrane integrity in given cell lines, they had a great influence on its hemolytic activity. The higher the aspect ratio is, the lower the hemolytic toxicity. This effect mainly contributed to differential silanol density of each nanoparticle. Larger aspect ratio means smaller surface area, logically less silanol exposed to RBCs, which subsequently yields little hemolytic activity. Besides the aspect ratio, the shape of MSN also has a significant influence on cellular uptake in vitro. Lin et al. demonstrated the effect of MSN shape (spherical- and tube-like morphology) on the endocytosis in different cell lines [114]. They found that this effect is morphology and cell line dependent. Chinese hamster ovarian (CHO) cells had a rapid and similar endocytosis speed and rate for sphere MSNs (80 to $150 \mathrm{~nm}$ ) and tube-shaped MSNs (aspect ratio of 6), while the endocytic capability of fibroblast cells for sphere MSNs was significantly higher than that for rod-like MSNs. 

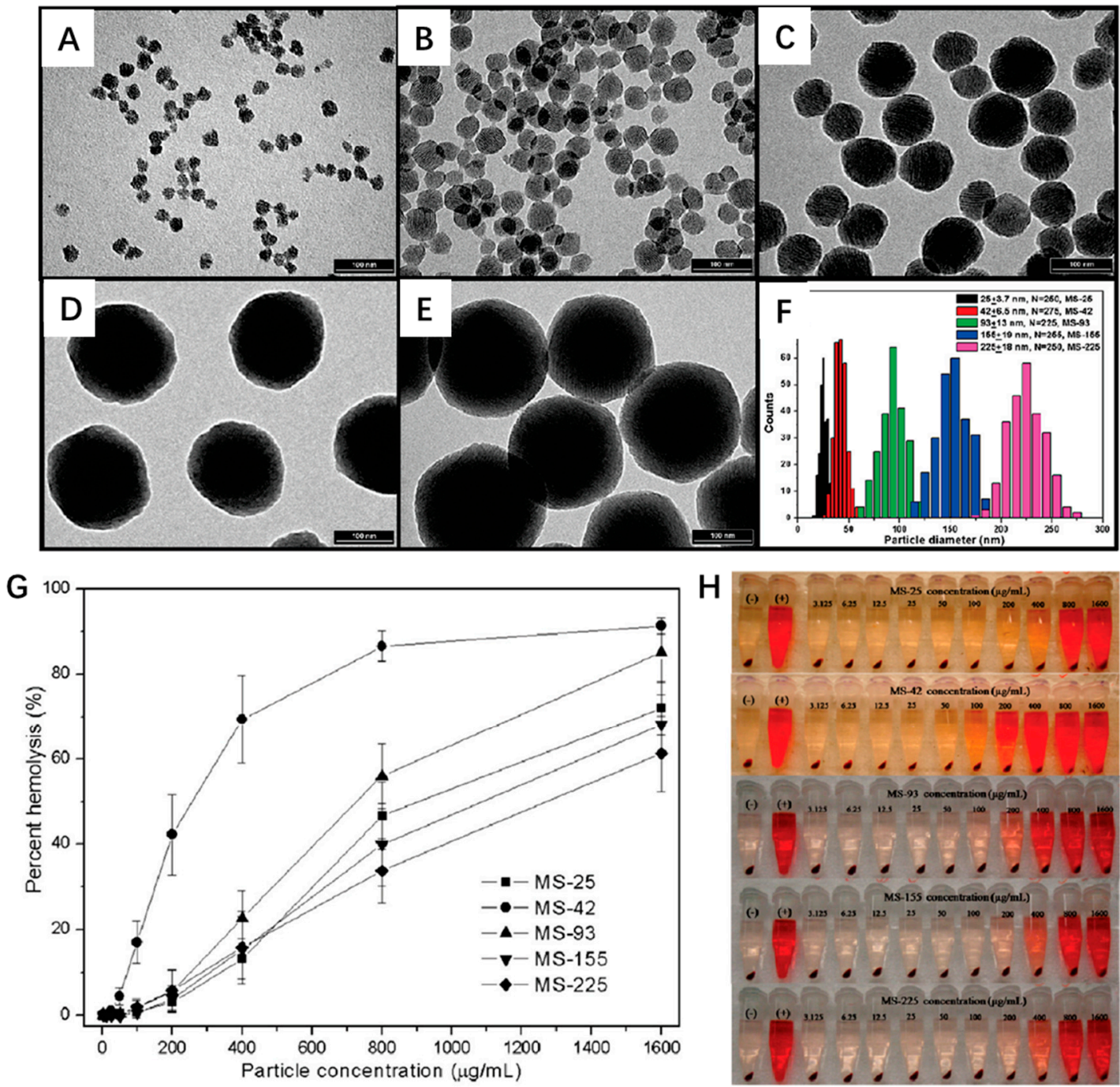

Figure 6. Impacts of mesoporous silica nanoparticle size on hemolytic activity. TEM of mesoporous silica nanoparticles with different size: (A) MS-25, $25 \mathrm{~nm}$; (B) MS-42, $42 \mathrm{~nm}$; (C) MS-93, $93 \mathrm{~nm}$; (D) MS-155, $155 \mathrm{~nm}$; (E) MS-225, $225 \mathrm{~nm}$; (F)The dynamic light scattering size (DLS) distributions of the five mesoporous silica nanoparticles; (G) Percentage of hemolysis of red blood cells (RBCs) incubation with different size MS for $3 \mathrm{~h}$ in various concentration. (H) The photographs of RBCs in G. Water $(+)$ and PBS (-) are used as positive and negative control, respectively [111].

The surface property or surface functionalization is another crucial parameter apart from size, which not only has significant influence on cargoes' delivery but is also involved in MSN vehicle biocompatibility. As mentioned above, abundant silanol groups exposed on a bared MSN surface provide facile rivet for surface modification. Different modifications could interact with cellular membrane lipids and proteins and disturb their structure and conformation. Positive charge reagents or polymers are commonly used in protein delivery MSN systems. It is well known that particles with cationic surface charge would induce intense immune response, cytotoxicity, and short circulation times compared with anionic and neutral ones. However, positive surface charge is of obvious superiority for transvascular transport and intracellular transport due to the generally negative potential of the cell membrane [115]. Thus, how to finely tune the surface modification for MSN is pivotal in improving MSN biocompatibility and efficacy. PEGylation is the most popular and efficient modification approach to improve nanoparticles' biocompatibility. It has been demonstrated that polyethylene glycols (PEGs) decorated on nanoparticles can form a hydrophilic corona around the particles, which will increase particle dispersity, decrease the endocytosis and increase circulation time 
in vivo by delaying opsonization [116,117]. After being modified with PEG, it is easy to imagine that the surface silanol groups on the MSNs would be masked by a PEG layer. Many studies have given plenty of robust evidence that the PEGylation in MSN could ameliorate the hemolytic cytotoxicity, decrease its endocytosis and distribution in mononuclear phagocytic system organs of the liver and spleen, and prolong its half-life in blood [118-123]. However, the induction of specific anti-PEG IgM after repeated injection of PEGylated particles would accelerate the blood clearance of PEGylated nanoparticles counterproductively [124] and also give rise to a hypersensitivity reaction led by complementary cascade activation [125]. Other surface functional groups have also been applied to improve MSN biocompatibility, manipulate their in vivo distribution and excretion, such as amino (-NH2), carboxyl (-COOH), phenyl (-Ph) and methyl phosphonate [32,126-128], even including some lipid layer [129-133] and bio-membranes derived from various cells [134-136].

\section{Conclusions and Outlook}

In this review, we mainly focus on research advances on MSN-based protein delivery. It is clear that MSN materials are promising candidate carriers for protein delivery in vitro and in vivo due to their specific structure and physicochemical property. First, their versatile and adjustable pore size and porosity make MSNs suitable for loading proteins cargos. Second, the simple surface functionality broadens their protein delivery ability and possibility, such as different kinds of proteins, co-delivery of proteins and other drugs, targeted protein transport, and various stimuli-responsive protein release methods. Third, their great biocompatibility bestows promising potential for future biomedical applications.

Besides the aforementioned advantages, there remain some significant challenges that should be investigated to enable the development of practical applications for MSN-based protein delivery systems. Apart from in vitro protein release profiles' investigation, much more attention should be paid to track in vivo navigation of proteins, especially their release in target tissues by using integrated multifunctional or multimode imaging methods. Although there has been some research into the development of such multifunctional MSNs, novel-innovative methods for functionalization remain limited. Protein structure is the base of its function. In view of the frangibility of proteins and complexity in a physiological and pathological conditions, there should be caution characterizing their structures, as well as the biofunction after their release from MSN in the targeted site. Toxicity is the major obstacle for the translation of nanomaterials from preclinical research to clinical application. Although most recent reports showed that MSN materials have little cytotoxicity, and are of great biocompatibility in vivo, much more work still needs to be performed to demonstrate comprehensively the biological safety of MSNs, such as the ultimate fates of MSNs after in vivo application.

Funding: The authors thank National Institutes of Health (1R15CA188847-01A1 and 1R01AG054839-01A1) for the financial support of the research.

Conflicts of Interest: The authors declare no conflict of interest.

\section{References}

1. Goeddel, D.V.; Kleid, D.G.; Bolivar, F.; Heyneker, H.L.; Yansura, D.G.; Crea, R.; Hirose, T.; Kraszewski, A.; Itakura, K.; Riggs, A.D. Expression in Escherichia coli of chemically synthesized genes for human insulin. Proc. Natl. Acad. Sci. USA 1979, 76, 106-110. [CrossRef]

2. Leader, B.; Baca, Q.J.; Golan, D.E. Protein therapeutics: A summary and pharmacological classification. Nat. Rev. Drug Discov. 2008, 7, 21. [CrossRef]

3. Malik, N.N. Drug discovery: Past, present and future. Drug Discov. Today 2008, 13, 909-912. [CrossRef]

4. Antosova, Z.; Mackova, M.; Kral, V.; Macek, T. Therapeutic application of peptides and proteins: Parenteral forever? Trends Biotechnol. 2009, 27, 628-635. [CrossRef]

5. Pisal, D.S.; Kosloski, M.P.; Balu-Iyer, S.V. Delivery of Therapeutic Proteins. J. Pharm. Sci. 2010, 99, 2557-2575. [CrossRef] 
6. Manning, M.C.; Chou, D.K.; Murphy, B.M.; Payne, R.W.; Katayama, D.S. Stability of Protein Pharmaceuticals: An Update. Pharm. Res. 2010, 27, 544-575. [CrossRef]

7. Jiskoot, W.; Randolph, T.W.; Volkin, D.B.; Middaugh, C.R.; Schoneich, C.; Winter, G.; Friess, W.; Crommelin, D.J.; Carpenter, J.F. Protein instability and immunogenicity: Roadblocks to clinical application of injectable protein delivery systems for sustained release. J. Pharm. Sci. 2012, 101, 946-954. [CrossRef]

8. Lu, Y.; Yang, J.; Sega, E. Issues related to targeted delivery of proteins and peptides. AAPS J. 2006, 8, E466-E478. [CrossRef]

9. Patton, J.; Bossard, M. Drug delivery strategies for proteins and peptides from discovery and development to life cycle management. Drug Deliv. Technol. 2004, 4, 73-77.

10. Caliceti, P.; Veronese, F.M. Pharmacokinetic and biodistribution properties of poly (ethylene glycol)-protein conjugates. Adv. Drug Deliv. Rev. 2003, 55, 1261-1277. [CrossRef]

11. Almeida, A.J.; Souto, E. Solid lipid nanoparticles as a drug delivery system for peptides and proteins. Adv. Drug Deliv. Rev. 2007, 59, 478-490. [CrossRef]

12. Begarani, F.; Cassano, D.; Margheritis, E.; Marotta, R.; Cardarelli, F.; Voliani, V. Silica-Based Nanoparticles for Protein Encapsulation and Delivery. Nanomaterials 2018, 8, 886. [CrossRef]

13. Gan, Q.; Wang, T. Chitosan nanoparticle as protein delivery carrier-Systematic examination of fabrication conditions for efficient loading and release. Colloids Surf. B Biointerfaces 2007, 59, 24-34. [CrossRef]

14. Hasadsri, L.; Kreuter, J.; Hattori, H.; Iwasaki, T.; George, J.M. Functional protein delivery into neurons using polymeric nanoparticles. J. Biol. Chem. 2009, 284, 6972-6981. [CrossRef]

15. Lu, Y.; Sun, W.; Gu, Z. Stimuli-responsive nanomaterials for therapeutic protein delivery. J. Control. Release 2014, 194, 1-19. [CrossRef]

16. Mamaeva, V.; Sahlgren, C.; Linden, M. Mesoporous silica nanoparticles in medicine-Recent advances. Adv. Drug Deliv. Rev. 2013, 65, 689-702. [CrossRef]

17. Martin-Ortigosa, S.; Peterson, D.J.; Valenstein, J.S.; Lin, V.S.; Trewyn, B.G.; Lyznik, L.A.; Wang, K. Mesoporous silica nanoparticle-mediated intracellular cre protein delivery for maize genome editing via loxP site excision. Plant Physiol. 2014, 164, 537-547. [CrossRef]

18. Mody, K.T.; Popat, A.; Mahony, D.; Cavallaro, A.S.; Yu, C.; Mitter, N. Mesoporous silica nanoparticles as antigen carriers and adjuvants for vaccine delivery. Nanoscale 2013, 5, 5167-5179. [CrossRef]

19. Argyo, C.; Weiss, V.; Bräuchle, C.; Bein, T. Multifunctional mesoporous silica nanoparticles as a universal platform for drug delivery. Chem. Mater. 2013, 26, 435-451. [CrossRef]

20. Wang, Y.; Zhao, Q.; Han, N.; Bai, L.; Li, J.; Liu, J.; Che, E.; Hu, L.; Zhang, Q.; Jiang, T.; et al. Mesoporous silica nanoparticles in drug delivery and biomedical applications. Nanomedicine 2015, 11, 313-327. [CrossRef]

21. Kresge, C.; Leonowicz, M.; Roth, W.J.; Vartuli, J.; Beck, J. Ordered mesoporous molecular sieves synthesized by a liquid-crystal template mechanism. Nature 1992, 359, 710. [CrossRef]

22. Baeza, A.; Colilla, M.; Vallet-Regí, M. Advances in mesoporous silica nanoparticles for targeted stimuli-responsive drug delivery. Expert Opin. Drug Deliv. 2015, 12, 319-337. [CrossRef]

23. Deodhar, G.V.; Adams, M.L.; Trewyn, B.G. Controlled release and intracellular protein delivery from mesoporous silica nanoparticles. Biotechnol. J. 2017, 12, 1600408. [CrossRef]

24. Vallet-Regi, M.; Ramila, A.; Del Real, R.; Pérez-Pariente, J. A new property of MCM-41: Drug delivery system. Chem. Mater. 2001, 13, 308-311. [CrossRef]

25. Chiang, Y.-D.; Lian, H.-Y.; Leo, S.-Y.; Wang, S.-G.; Yamauchi, Y.; Wu, K.C.-W. Controlling particle size and structural properties of mesoporous silica nanoparticles using the Taguchi method. J. Phys. Chem. C 2011, 115, 13158-13165. [CrossRef]

26. Yamada, H.; Urata, C.; Higashitamori, S.; Aoyama, Y.; Yamauchi, Y.; Kuroda, K. Critical roles of cationic surfactants in the preparation of colloidal mesostructured silica nanoparticles: Control of mesostructure, particle size, and dispersion. ACS Appl. Mater. Interfaces 2014, 6, 3491-3500. [CrossRef]

27. Knežević, N.Ž.; Durand, J.-O. Large pore mesoporous silica nanomaterials for application in delivery of biomolecules. Nanoscale 2015, 7, 2199-2209. [CrossRef]

28. Xu, B.; Su, Y.; Chen, L.; Cai, J.; Huang, B. Preparation of mesoporous silica nanoparticles with controlled pore size, particle diameter, morphology, and structure by two-step process of chlorosilane residue. Ceram. Int. 2018, 44, 22241-22248. [CrossRef] 
29. Hao, N.; Tang, F.; Li, L. MCM-41 mesoporous silica sheet with ordered perpendicular nanochannels for protein delivery and the assembly of Ag nanoparticles in catalytic applications. Microporous Mesoporous Mater. 2015, 218, 223-227. [CrossRef]

30. Zhang, H.; Xu, H.; Wu, M.; Zhong, Y.; Wang, D.; Jiao, Z. A soft-hard template approach towards hollow mesoporous silica nanoparticles with rough surfaces for controlled drug delivery and protein adsorption. J. Mater. Chem. B 2015, 3, 6480-6489. [CrossRef]

31. Slowing, I.I.; Trewyn, B.G.; Lin, V.S.-Y. Mesoporous silica nanoparticles for intracellular delivery of membrane-impermeable proteins. J. Am. Chem. Soc. 2007, 129, 8845-8849. [CrossRef]

32. Slowing, I.; Trewyn, B.G.; Lin, V.S.-Y. Effect of surface functionalization of MCM-41-type mesoporous silica nanoparticles on the endocytosis by human cancer cells. J. Am. Chem. Soc. 2006, 128, 14792-14793. [CrossRef]

33. Lin, Y.-S.; Tsai, C.-P.; Huang, H.-Y.; Kuo, C.-T.; Hung, Y.; Huang, D.-M.; Chen, Y.-C.; Mou, C.-Y. Well-ordered mesoporous silica nanoparticles as cell markers. Chem. Mater. 2005, 17, 4570-4573. [CrossRef]

34. Méndez, J.; Morales Cruz, M.; Delgado, Y.; Figueroa, C.M.; Orellano, E.A.; Morales, M.; Monteagudo, A.; Griebenow, K. Delivery of chemically glycosylated cytochrome c immobilized in mesoporous silica nanoparticles induces apoptosis in HeLa cancer cells. Mol. Pharm. 2013, 11, 102-111.

35. Lei, C.; Shin, Y.; Magnuson, J.K.; Fryxell, G.; Lasure, L.L.; Elliott, D.C.; Liu, J.; Ackerman, E.J. Characterization of functionalized nanoporous supports for protein confinement. Nanotechnology 2006, 17, 5531. [CrossRef]

36. Hartono, S.B.; Qiao, S.Z.; Liu, J.; Jack, K.; Ladewig, B.P.; Hao, Z.; Lu, G.Q.M. Functionalized mesoporous silica with very large pores for cellulase immobilization. J. Phys. Chem. C 2010, 114, 8353-8362. [CrossRef]

37. Kim, S.-I.; Pham, T.T.; Lee, J.-W.; Roh, S.-H. Releasing properties of proteins on SBA-15 spherical nanoparticles functionalized with aminosilanes. J. Nanosci. Nanotechnol. 2010, 10, 3467-3472. [CrossRef]

38. Lee, J.-W.; Tra, P.T.; Kim, S.-I.; Roh, S.-H. Adsorption properties of proteins on SBA-15 nanoparticles functionalized with aminosilanes. J. Nanosci. Nanotechnol. 2008, 8, 5152-5157. [CrossRef]

39. Zhao, Y.; Trewyn, B.G.; Slowing, I.I.; Lin, V.S.-Y. Mesoporous silica nanoparticle-based double drug delivery system for glucose-responsive controlled release of insulin and cyclic AMP. J. Am. Chem. Soc. 2009, 131, 8398-8400. [CrossRef]

40. Gan, Q.; Zhu, J.; Yuan, Y.; Liu, H.; Qian, J.; Li, Y.; Liu, C. A dual-delivery system of pH-responsive chitosan-functionalized mesoporous silica nanoparticles bearing BMP-2 and dexamethasone for enhanced bone regeneration. J. Mater. Chem. B 2015, 3, 2056-2066. [CrossRef]

41. Lin, Y.-H.; Chen, Y.-P.; Liu, T.-P.; Chien, F.-C.; Chou, C.-M.; Chen, C.-T.; Mou, C.-Y. Approach to deliver two antioxidant enzymes with mesoporous silica nanoparticles into cells. ACS Appl. Mater. Interfaces 2016, 8, 17944-17954. [CrossRef]

42. Chen, Y.-P.; Chen, C.-T.; Hung, Y.; Chou, C.-M.; Liu, T.-P.; Liang, M.-R.; Chen, C.-T.; Mou, C.-Y. A new strategy for intracellular delivery of enzyme using mesoporous silica nanoparticles: Superoxide dismutase. J. Am. Chem. Soc. 2013, 135, 1516-1523. [CrossRef]

43. Gan, Q.; Zhu, J.; Yuan, Y.; Liu, C. pH-Responsive $\mathrm{Fe}_{3} \mathrm{O}_{4}$ nanopartilces-capped mesoporous silica supports for protein delivery. J. Nanosci. Nanotechnol. 2016, 16, 5470-5479. [CrossRef]

44. Sun, X.; Zhao, Y.; Lin, V.S.-Y.; Slowing, I.I.; Trewyn, B.G. Luciferase and luciferin co-immobilized mesoporous silica nanoparticle materials for intracellular biocatalysis. J. Am. Chem. Soc. 2011, 133, 18554-18557. [CrossRef]

45. Lim, J.-S.; Lee, K.; Choi, J.-N.; Hwang, Y.-K.; Yun, M.-Y.; Kim, H.-J.; Won, Y.S.; Kim, S.-J.; Kwon, H.; Huh, S. Intracellular protein delivery by hollow mesoporous silica capsules with a large surface hole. Nanotechnology 2012, 23, 085101. [CrossRef]

46. Sharif, F.; Porta, F.; Meijer, A.H.; Kros, A.; Richardson, M.K. Mesoporous silica nanoparticles as a compound delivery system in zebrafish embryos. Int. J. Nanomed. 2012, 7, 1875. [CrossRef]

47. Cheng, K.; El-Boubbou, K.; Landry, C.C. Binding of HIV-1 gp120 glycoprotein to silica nanoparticles modified with CD4 glycoprotein and CD4 peptide fragments. ACS Appl. Mater. Interfaces 2011, 4, 235-243. [CrossRef]

48. Li, Y.; Zhou, G.; Qiao, W.; Wang, Y. Immobilization of porcine pancreas lipase on fiber-like SBA-15 mesoporous material. Mater. Sci. Eng. B 2009, 162, 120-126. [CrossRef]

49. Xu, C.; Yu, M.; Noonan, O.; Zhang, J.; Song, H.; Zhang, H.; Lei, C.; Niu, Y.; Huang, X.; Yang, Y. Core-Cone Structured Monodispersed Mesoporous Silica Nanoparticles with Ultra-large Cavity for Protein Delivery. Small 2015, 11, 5949-5955. [CrossRef] 
50. Martin-Ortigosa, S.; Valenstein, J.S.; Lin, V.S.Y.; Trewyn, B.G.; Wang, K. Gold functionalized mesoporous silica nanoparticle mediated protein and DNA codelivery to plant cells via the biolistic method. Adv. Funct. Mater. 2012, 22, 3576-3582. [CrossRef]

51. Yagüe, C.; Moros, M.; Grazu, V.; Arruebo, M.; Santamaria, J. Synthesis and stealthing study of bare and PEGylated silica micro-and nanoparticles as potential drug-delivery vectors. Chem. Eng. J. 2008, 137, 45-53. [CrossRef]

52. Chong, A.M.; Zhao, X. Design of large-pore mesoporous materials for immobilization of penicillin G acylase biocatalyst. Catal. Today 2004, 93, 293-299. [CrossRef]

53. Mendez, J.; Monteagudo, A.; Griebenow, K. Stimulus-responsive controlled release system by covalent immobilization of an enzyme into mesoporous silica nanoparticles. Bioconjug. Chem. 2012, 23, 698-704. [CrossRef] [PubMed]

54. Baeza, A.; Guisasola, E.; Ruiz-Hernández, E.; Vallet-Regí, M. Magnetically triggered multidrug release by hybrid mesoporous silica nanoparticles. Chem. Mater. 2012, 24, 517-524. [CrossRef]

55. Katiyar, A.; Pinto, N.G. Visualization of size-selective protein separations on spherical mesoporous silicates. Small 2006, 2, 644-648. [CrossRef]

56. Chen, L.; Zhu, G.; Zhang, D.; Zhao, H.; Guo, M.; Shi, W.; Qiu, S. Novel mesoporous silica spheres with ultra-large pore sizes and their application in protein separation. J. Mater. Chem. 2009, 19. [CrossRef]

57. Gao, Z.; Zharov, I. Large pore mesoporous silica nanoparticles by templating with a nonsurfactant molecule, tannic acid. Chem. Mater. 2014, 26, 2030-2037. [CrossRef]

58. Fuertes, A.B.; Valle-Vigón, P.; Sevilla, M. Synthesis of colloidal silica nanoparticles of a tunable mesopore size and their application to the adsorption of biomolecules. J. Colloid Interface Sci. 2010, 349, 173-180. [CrossRef] [PubMed]

59. Kim, M.-H.; Na, H.-K.; Kim, Y.-K.; Ryoo, S.-R.; Cho, H.S.; Lee, K.E.; Jeon, H.; Ryoo, R.; Min, D.-H. Facile synthesis of monodispersed mesoporous silica nanoparticles with ultralarge pores and their application in gene delivery. ACS Nano 2011, 5, 3568-3576. [CrossRef]

60. Jana, S.K.; Nishida, R.; Shindo, K.; Kugita, T.; Namba, S. Pore size control of mesoporous molecular sieves using different organic auxiliary chemicals. Microporous Mesoporous Mater. 2004, 68, 133-142. [CrossRef]

61. Eltohamy, M.; Shin, U.S.; Kim, H.-W. Silica nanoparticles with enlarged nanopore size for the loading and release of biological proteins. Mater. Lett. 2011, 65, 3570-3573. [CrossRef]

62. Blin, J.; Su, B. Tailoring pore size of ordered mesoporous silicas using one or two organic auxiliaries as expanders. Langmuir 2002, 18, 5303-5308. [CrossRef]

63. Sayari, A.; Kruk, M.; Jaroniec, M.; Moudrakovski, I.L. New approaches to pore size engineering of mesoporous silicates. Adv. Mater. 1998, 10, 1376-1379. [CrossRef]

64. Kao, K.-C.; Mou, C.-Y. Pore-expanded mesoporous silica nanoparticles with alkanes/ethanol as pore expanding agent. Microporous Mesoporous Mater. 2013, 169, 7-15. [CrossRef]

65. Fan, J.; Yu, C.; Lei, J.; Zhang, Q.; Li, T.; Tu, B.; Zhou, W.; Zhao, D. Low-temperature strategy to synthesize highly ordered mesoporous silicas with very large pores. J. Am. Chem. Soc. 2005, 127, 10794-10795. [CrossRef] [PubMed]

66. Zhuravlev, L. The surface chemistry of amorphous silica. Zhuravlev model. Colloids Surf. A Physicochem. Eng. Asp. 2000, 173, 1-38. [CrossRef]

67. Vivero-Escoto, J.L.; Slowing, I.I.; Trewyn, B.G.; Lin, V.S.Y. Mesoporous silica nanoparticles for intracellular controlled drug delivery. Small 2010, 6, 1952-1967. [CrossRef]

68. Song, S.-W.; Hidajat, K.; Kawi, S. pH-controllable drug release using hydrogel encapsulated mesoporous silica. Chem. Commun. 2007, 4396-4398. [CrossRef] [PubMed]

69. Park, H.S.; Kim, C.W.; Lee, H.J.; Choi, J.H.; Lee, S.G.; Yun, Y.P.; Kwon, I.C.; Lee, S.J.; Jeong, S.Y.; Lee, S.C. A mesoporous silica nanoparticle with charge-convertible pore walls for efficient intracellular protein delivery. Nanotechnology 2010, 21, 225101. [CrossRef]

70. Liu, H.J.; Luan, X.; Feng, H.Y.; Dong, X.; Yang, S.C.; Chen, Z.J.; Cai, Q.Y.; Lu, Q.; Zhang, Y.; Sun, P. Integrated Combination Treatment Using a "Smart" Chemotherapy and MicroRNA Delivery System Improves Outcomes in an Orthotopic Colorectal Cancer Model. Adv. Funct. Mater. 2018, 28, 1801118. [CrossRef] 
71. Ashley, C.E.; Carnes, E.C.; Epler, K.E.; Padilla, D.P.; Phillips, G.K.; Castillo, R.E.; Wilkinson, D.C.; Wilkinson, B.S.; Burgard, C.A.; Kalinich, R.M. Delivery of small interfering RNA by peptide-targeted mesoporous silica nanoparticle-supported lipid bilayers. ACS Nano 2012, 6, 2174-2188. [CrossRef] [PubMed]

72. Li, Z.-Y.; Hu, J.-J.; Xu, Q.; Chen, S.; Jia, H.-Z.; Sun, Y.-X.; Zhuo, R.-X.; Zhang, X.-Z. A redox-responsive drug delivery system based on RGD containing peptide-capped mesoporous silica nanoparticles. J. Mater. Chem. B 2015, 3, 39-44. [CrossRef]

73. Baeza, A.; Vallet-Regi, M. Targeted Mesoporous Silica Nanocarriers in Oncology. Curr. Drug Targets 2018, 19, 213-224. [CrossRef]

74. Martínez-Carmona, M.; Lozano, D.; Colilla, M.; Vallet-Regí, M. Lectin-conjugated pH-responsive mesoporous silica nanoparticles for targeted bone cancer treatment. Acta Biomater. 2018, 65, 393-404. [CrossRef]

75. Tsai, C.-P.; Chen, C.-Y.; Hung, Y.; Chang, F.-H.; Mou, C.-Y. Monoclonal antibody-functionalized mesoporous silica nanoparticles (MSN) for selective targeting breast cancer cells. J. Mater. Chem. 2009, 19, 5737-5743. [CrossRef]

76. Chen, F.; Hong, H.; Zhang, Y.; Valdovinos, H.F.; Shi, S.; Kwon, G.S.; Theuer, C.P.; Barnhart, T.E.; Cai, W. In vivo tumor targeting and image-guided drug delivery with antibody-conjugated, radiolabeled mesoporous silica nanoparticles. ACS Nano 2013, 7, 9027-9039. [CrossRef]

77. Mandal, T.; Beck, M.; Kirsten, N.; Lindén, M.; Buske, C. Targeting murine leukemic stem cells by antibody functionalized mesoporous silica nanoparticles. Sci. Rep. 2018, 8, 989. [CrossRef]

78. Chen, Z.; Sun, M.; Luo, F.; Xu, K.; Lin, Z.; Zhang, L. Stimulus-response click chemistry based aptamer-functionalized mesoporous silica nanoparticles for fluorescence detection of thrombin. Talanta 2018, 178, 563-568. [CrossRef] [PubMed]

79. Hanafi-Bojd, M.Y.; Moosavian Kalat, S.A.; Taghdisi, S.M.; Ansari, L.; Abnous, K.; Malaekeh-Nikouei, B. MUC1 Aptamer-conjugated mesoporous silica nanoparticles effectively target breast cancer cells. Drug Dev. Ind. Pharm. 2018, 44, 13-18. [CrossRef] [PubMed]

80. He, L.; Lai, H.; Chen, T. Dual-function nanosystem for synergetic cancer chemo-/radiotherapy through ROS-mediated signaling pathways. Biomaterials 2015, 51, 30-42. [CrossRef]

81. Bourguignon, L.Y.; Spevak, C.C.; Wong, G.; Xia, W.; Gilad, E. Hyaluronan-CD44 interaction with PKC-epsilon promotes oncogenic signaling by the stem cell marker, Nanog and the production of microRNA-21 leading to downregulation of the tumor suppressor protein, PDCD4, anti-apoptosis and chemotherapy resistance in breast tumor cells. J. Biol. Chem. 2009. [CrossRef]

82. Cain, J.W.; Hauptschein, R.S.; Stewart, J.K.; Bagci, T.; Sahagian, G.G.; Jay, D.G. Identification of CD44 as a surface biomarker for drug resistance by surface proteome signature technology. Mol. Cancer Res. 2011, 9 , 637-647. [CrossRef]

83. Wang, X.; Liu, Y.; Wang, S.; Shi, D.; Zhou, X.; Wang, C.; Wu, J.; Zeng, Z.; Li, Y.; Sun, J.; et al. CD44-engineered mesoporous silica nanoparticles for overcoming multidrug resistance in breast cancer. Appl. Surf. Sci. 2015, 332, 308-317. [CrossRef]

84. Liu, D.; Bimbo, L.M.; Makila, E.; Villanova, F.; Kaasalainen, M.; Herranz-Blanco, B.; Caramella, C.M.; Lehto, V.P.; Salonen, J.; Herzig, K.H.; et al. Co-delivery of a hydrophobic small molecule and a hydrophilic peptide by porous silicon nanoparticles. J. Control. Release 2013, 170, 268-278. [CrossRef]

85. Zhu, M.; Zhu, Y.; Zhang, L.; Shi, J. Preparation of chitosan/mesoporous silica nanoparticle composite hydrogels for sustained co-delivery of biomacromolecules and small chemical drugs. Sci. Technol. Adv. Mater. 2013, 14, 045005. [CrossRef]

86. Shiino, D.; Murata, Y.; Kubo, A.; Kim, Y.J.; Kataoka, K.; Koyama, Y.; Kikuchi, A.; Yokoyama, M.; Sakurai, Y.; Okano, T. Amine containing phenylboronic acid gel for glucose-responsive insulin release under physiological pH. J. Control. Release 1995, 37, 269-276. [CrossRef]

87. Tang, F.; Li, L.; Chen, D. Mesoporous silica nanoparticles: Synthesis, biocompatibility and drug delivery. Adv. Mater. 2012, 24, 1504-1534. [CrossRef]

88. Mura, S.; Nicolas, J.; Couvreur, P. Stimuli-responsive nanocarriers for drug delivery. Nat. Mater. 2013, $12,991$. [CrossRef]

89. Gao, W.; Chan, J.M.; Farokhzad, O.C. pH-responsive nanoparticles for drug delivery. Mol. Pharm. 2010, 7, 1913-1920. [CrossRef] [PubMed]

90. Gu, J.; Cheng, W.-P.; Liu, J.; Lo, S.-Y.; Smith, D.; Qu, X.; Yang, Z. pH-triggered reversible “stealth" polycationic micelles. Biomacromolecules 2007, 9, 255-262. [CrossRef] 
91. Wu, X.; Wu, S.; Yang, L.; Han, J.; Han, S. Cytosolic delivery of proteins mediated by aldehyde-displaying silica nanoparticles with $\mathrm{pH}$-responsive characteristics. J. Mater. Chem. 2012, 22. [CrossRef]

92. Tian, Z.; Xu, Y.; Zhu, Y. Aldehyde-functionalized dendritic mesoporous silica nanoparticles as potential nanocarriers for $\mathrm{pH}$-responsive protein drug delivery. Mater. Sci. Eng. C Mater. Biol. Appl. 2017, 71, 452-459. [CrossRef]

93. Schafer, F.Q.; Buettner, G.R. Redox environment of the cell as viewed through the redox state of the glutathione disulfide/glutathione couple. Free Radic. Biol. Med. 2001, 30, 1191-1212. [CrossRef]

94. Russo, A.; DeGraff, W.; Friedman, N.; Mitchell, J.B. Selective modulation of glutathione levels in human normal versus tumor cells and subsequent differential response to chemotherapy drugs. Cancer Res. 1986, $46,2845-2848$.

95. Yang, Y.; Wan, J.; Niu, Y.; Gu, Z.; Zhang, J.; Yu, M.; Yu, C. Structure-Dependent and Glutathione-Responsive Biodegradable Dendritic Mesoporous Organosilica Nanoparticles for Safe Protein Delivery. Chem. Mater. 2016, 28, 9008-9016. [CrossRef]

96. Hu, Q.; Katti, P.S.; Gu, Z. Enzyme-responsive nanomaterials for controlled drug delivery. Nanoscale 2014, 6, 12273-12286. [CrossRef]

97. Zhu, L.; Kate, P.; Torchilin, V.P. Matrix metalloprotease 2-responsive multifunctional liposomal nanocarrier for enhanced tumor targeting. ACS Nano 2012, 6, 3491-3498. [CrossRef] [PubMed]

98. Dong, X.; Liu, H.-J.; Feng, H.-Y.; Yang, S.-C.; Liu, X.-L.; Lai, X.; Lu, Q.; Lovell, J.F.; Chen, H.-Z.; Fang, C. Enhanced Drug Delivery by Nanoscale Integration of a Nitric Oxide Donor to Induce Tumor Collagen Depletion. Nano Lett. 2019, 19, 997-1008. [CrossRef]

99. Liu, J.; Zhang, B.; Luo, Z.; Ding, X.; Li, J.; Dai, L.; Zhou, J.; Zhao, X.; Ye, J.; Cai, K. Enzyme responsive mesoporous silica nanoparticles for targeted tumor therapy in vitro and in vivo. Nanoscale 2015, 7, 3614-3626. [CrossRef]

100. Deshayes, S.; Cabral, H.; Ishii, T.; Miura, Y.; Kobayashi, S.; Yamashita, T.; Matsumoto, A.; Miyahara, Y.; Nishiyama, N.; Kataoka, K. Phenylboronic acid-installed polymeric micelles for targeting sialylated epitopes in solid tumors. J. Am. Chem. Soc. 2013, 135, 15501-15507. [CrossRef]

101. Yu, E.; Lo, A.; Jiang, L.; Petkus, B.; Ercan, N.I.; Stroeve, P. Improved controlled release of protein from expanded-pore mesoporous silica nanoparticles modified with co-functionalized poly(n-isopropylacrylamide) and poly(ethylene glycol) (PNIPAM-PEG). Colloids Surf. B Biointerfaces 2017, 149, 297-300. [CrossRef] [PubMed]

102. Omar, H.; Croissant, J.G.; Alamoudi, K.; Alsaiari, S.; Alradwan, I.; Majrashi, M.A.; Anjum, D.H.; Martins, P.; Laamarti, R.; Eppinger, J. Biodegradable magnetic silica@ iron oxide nanovectors with ultra-large mesopores for high protein loading, magnetothermal release, and delivery. J. Control. Release 2017, 259, 187-194. [CrossRef]

103. Park, C.; Lee, K.; Kim, C. Photoresponsive cyclodextrin-covered nanocontainers and their sol-gel transition induced by molecular recognition. Angew. Chem. Int. Ed. 2009, 48, 1275-1278. [CrossRef] [PubMed]

104. Knežević, N.Ž.; Trewyn, B.G.; Lin, V.S.-Y. Functionalized mesoporous silica nanoparticle-based visible light responsive controlled release delivery system. Chem. Commun. 2011, 47, 2817-2819. [CrossRef] [PubMed]

105. Wan, X.; Liu, T.; Hu, J.; Liu, S. Photo-degradable, protein-polyelectrolyte complex-coated, mesoporous silica nanoparticles for controlled co-release of protein and model drugs. Macromol. Rapid. Commun. 2013, 34, 341-347. [CrossRef]

106. Chang, J.-S.; Chang, K.L.B.; Hwang, D.-F.; Kong, Z.-L. In vitro cytotoxicitiy of silica nanoparticles at high concentrations strongly depends on the metabolic activity type of the cell line. Environ. Sci. Technol. 2007, 41, 2064-2068. [CrossRef] [PubMed]

107. Lin, W.; Huang, Y.-w.; Zhou, X.-D.; Ma, Y. In vitro toxicity of silica nanoparticles in human lung cancer cells. Toxicol. Appl. Pharmacol. 2006, 217, 252-259. [CrossRef]

108. Tao, Z.; Morrow, M.P.; Asefa, T.; Sharma, K.K.; Duncan, C.; Anan, A.; Penefsky, H.S.; Goodisman, J.; Souid, A.-K. Mesoporous silica nanoparticles inhibit cellular respiration. Nano Lett. 2008, 8, 1517-1526. [CrossRef]

109. Lu, F.; Wu, S.H.; Hung, Y.; Mou, C.Y. Size effect on cell uptake in well-suspended, uniform mesoporous silica nanoparticles. Small 2009, 5, 1408-1413. [CrossRef]

110. He, Q.; Zhang, Z.; Gao, Y.; Shi, J.; Li, Y. Intracellular localization and cytotoxicity of spherical mesoporous silica nano-and microparticles. Small 2009, 5, 2722-2729. [CrossRef] 
111. Lin, Y.-S.; Haynes, C.L. Impacts of mesoporous silica nanoparticle size, pore ordering, and pore integrity on hemolytic activity. J. Am. Chem. Soc. 2010, 132, 4834-4842. [CrossRef] [PubMed]

112. Slowing, I.I.; Wu, C.W.; Vivero-Escoto, J.L.; Lin, V.S.Y. Mesoporous silica nanoparticles for reducing hemolytic activity towards mammalian red blood cells. Small 2009, 5, 57-62. [CrossRef] [PubMed]

113. Yu, T.; Malugin, A.; Ghandehari, H. Impact of silica nanoparticle design on cellular toxicity and hemolytic activity. ACS Nano 2011, 5, 5717-5728. [CrossRef]

114. Trewyn, B.G.; Nieweg, J.A.; Zhao, Y.; Lin, V.S.Y. Biocompatible mesoporous silica nanoparticles with different morphologies for animal cell membrane penetration. Chem. Eng. J. 2008, 137, 23-29. [CrossRef]

115. Nel, A.E.; Mädler, L.; Velegol, D.; Xia, T.; Hoek, E.M.; Somasundaran, P.; Klaessig, F.; Castranova, V.; Thompson, M. Understanding biophysicochemical interactions at the nano-bio interface. Nat. Mater. 2009, 8, 543. [CrossRef] [PubMed]

116. Veronese, F.M.; Pasut, G. PEGylation, successful approach to drug delivery. Drug Discov. Today 2005, 10, 1451-1458. [CrossRef]

117. Tao, Z.; Toms, B.B.; Goodisman, J.; Asefa, T. Mesoporosity and functional group dependent endocytosis and cytotoxicity of silica nanomaterials. Chem. Res. Toxicol. 2009, 22, 1869-1880. [CrossRef]

118. Ma, K.; Zhang, D.; Cong, Y.; Wiesner, U. Elucidating the mechanism of silica nanoparticle PEGylation processes using fluorescence correlation spectroscopies. Chem. Mater. 2016, 28, 1537-1545. [CrossRef]

119. Yuan, Q.; Wang, K.; Zhang, X.; Zhang, X.; Wei, Y. New Method to Determine the Effect of Surface PEGylation on Cellular Uptake Efficiency of Mesoporous Silica Nanoparticles with AIEgens. Macromol. Chem. Phys. 2018, 219, 1800034. [CrossRef]

120. Cauda, V.; Argyo, C.; Bein, T. Impact of different PEGylation patterns on the long-term bio-stability of colloidal mesoporous silica nanoparticles. J. Mater. Chem. 2010, 20, 8693-8699. [CrossRef]

121. Huang, L.; Liu, M.; Mao, L.; Huang, Q.; Huang, H.; Wan, Q.; Tian, J.; Wen, Y.; Zhang, X.; Wei, Y. Surface PEGylation of mesoporous silica materials via surface-initiated chain transfer free radical polymerization: Characterization and controlled drug release. Mater. Sci. Eng. C 2017, 81, 57-65. [CrossRef] [PubMed]

122. He, X.; Nie, H.; Wang, K.; Tan, W.; Wu, X.; Zhang, P. In vivo study of biodistribution and urinary excretion of surface-modified silica nanoparticles. Anal. Chem. 2008, 80, 9597-9603. [CrossRef] [PubMed]

123. Zhang, Q.; Zhao, H.; Li, D.; Liu, L.; Du, S. A surface-grafted ligand functionalization strategy for coordinate binding of doxorubicin at surface of PEGylated mesoporous silica nanoparticles: Toward pH-responsive drug delivery. Colloids Surf. B Biointerfaces 2017, 149, 138-145. [CrossRef] [PubMed]

124. Ishida, T.; Ichihara, M.; Wang, X.; Yamamoto, K.; Kimura, J.; Majima, E.; Kiwada, H. Injection of PEGylated liposomes in rats elicits PEG-specific IgM, which is responsible for rapid elimination of a second dose of PEGylated liposomes. J. Control. Release 2006, 112, 15-25. [CrossRef] [PubMed]

125. Moghimi, S.M.; Hamad, I. Liposome-mediated triggering of complement cascade. J. Liposome Res. 2008, 18, 195-209. [CrossRef] [PubMed]

126. Blumen, S.R.; Cheng, K.; Ramos-Nino, M.E.; Taatjes, D.J.; Weiss, D.J.; Landry, C.C.; Mossman, B.T. Unique uptake of acid-prepared mesoporous spheres by lung epithelial and mesothelioma cells. Am. J. Respir. Cell Mol. Biol. 2007, 36, 333-342. [CrossRef]

127. Di Pasqua, A.J.; Sharma, K.K.; Shi, Y.-L.; Toms, B.B.; Ouellette, W.; Dabrowiak, J.C.; Asefa, T. Cytotoxicity of mesoporous silica nanomaterials. J. Inorg. Biochem. 2008, 102, 1416-1423. [CrossRef]

128. Souris, J.S.; Lee, C.-H.; Cheng, S.-H.; Chen, C.-T.; Yang, C.-S.; Ja-an, A.H.; Mou, C.-Y.; Lo, L.-W. Surface charge-mediated rapid hepatobiliary excretion of mesoporous silica nanoparticles. Biomaterials 2010, 31, 5564-5574. [CrossRef]

129. Wang, L.-S.; Wu, L.-C.; Lu, S.-Y.; Chang, L.-L.; Teng, I.-T.; Yang, C.-M.; Ho, J.-A.A. Biofunctionalized phospholipid-capped mesoporous silica nanoshuttles for targeted drug delivery: Improved water suspensibility and decreased nonspecific protein binding. ACS Nano 2010, 4, 4371-4379. [CrossRef]

130. Durfee, P.N.; Lin, Y.-S.; Dunphy, D.R.; Muñiz, A.E.J.; Butler, K.S.; Humphrey, K.R.; Lokke, A.J.; Agola, J.O.; Chou, S.S.; Chen, I.-M. Mesoporous silica nanoparticle-supported lipid bilayers (protocells) for active targeting and delivery to individual leukemia cells. ACS Nano 2016, 10, 8325-8345. [CrossRef]

131. Butler, K.S.; Durfee, P.N.; Theron, C.; Ashley, C.E.; Carnes, E.C.; Brinker, C.J. Protocells: Modular Mesoporous Silica Nanoparticle-Supported Lipid Bilayers for Drug Delivery. Small 2016, 12, 2173-2185. [CrossRef] [PubMed] 
132. Sun, Q.; You, Q.; Wang, J.; Liu, L.; Wang, Y.; Song, Y.; Cheng, Y.; Wang, S.; Tan, F.; Li, N. Theranostic Nanoplatform: Triple-Modal Imaging-Guided Synergistic Cancer Therapy Based on Liposome-Conjugated Mesoporous Silica Nanoparticles. ACS Appl. Mater. Interfaces 2018, 10, 1963-1975. [CrossRef] [PubMed]

133. Li, Z.; Zhang, Y.; Zhang, K.; Wu, Z.; Feng, N. Biotinylated-lipid bilayer coated mesoporous silica nanoparticles for improving the bioavailability and anti-leukaemia activity of Tanshinone IIA. Artif. Cells Nanomed. Biotechnol. 2018, 1-10. [CrossRef] [PubMed]

134. Xuan, M.; Shao, J.; Zhao, J.; Li, Q.; Dai, L.; Li, J. Magnetic mesoporous silica nanoparticles cloaked by red blood cell membranes: Applications in cancer therapy. Angew. Chem. Int. Ed. 2018, 57, 6049-6053. [CrossRef] [PubMed]

135. Tu, J.; Bussmann, J.; Du, G.; Gao, Y.; Bouwstra, J.A.; Kros, A. Lipid bilayer-coated mesoporous silica nanoparticles carrying bovine hemoglobin towards an erythrocyte mimic. Int. J. Pharm. 2018, 543, 169-178. [CrossRef] [PubMed]

136. Xuan, M.; Shao, J.; Dai, L.; He, Q.; Li, J. Macrophage cell membrane camouflaged mesoporous silica nanocapsules for in vivo cancer therapy. Adv. Healthc. Mater. 2015, 4, 1645-1652. [CrossRef] [PubMed]

(C) 2019 by the authors. Licensee MDPI, Basel, Switzerland. This article is an open access article distributed under the terms and conditions of the Creative Commons Attribution (CC BY) license (http://creativecommons.org/licenses/by/4.0/). 